\title{
molecules
}

ISSN 1420-3049

www.mdpi.com/journal/molecules

Article

\section{Diterpenes Synthesized from the Natural Serrulatane Leubethanol and Their in Vitro Activities against Mycobacterium tuberculosis}

\author{
Ricardo Escarcena ${ }^{1, \dagger}$, Jonathan Perez-Meseguer ${ }^{2, \dagger}$, Esther del Olmo ${ }^{1, *}$, \\ Blanca Alanis-Garza ${ }^{2, \dagger}$, Elvira Garza-González ${ }^{3, \dagger}$, Ricardo Salazar-Aranda ${ }^{2, \dagger}$ \\ and Noemí Waksman de Torres ${ }^{2, \uparrow}$
}

1 Department of Pharmaceutical Chemistry, Faculty of Pharmacy, CIETUS, IBSAL, Universidad de Salamanca, 37007-Salamanca, Spain; E-Mail: ricar@usal.es

2 Department of Analytical Chemistry, Faculty of Medicine, Universidad Autónoma de Nuevo Leon, PO Box 2316, Sucursal Tecnológico, Monterrey, NL 64841, Mexico;

E-Mails: jonathanmeseguer@hotmail.com (J.P.-M.); alanisaliciab@yahoo.com.mx (B.A.-G.); salazar121212@yahoo.com.mx (R.S.-A.);nwaksman@gmail.com (N.W.T.)

3 Servicio de Gastroenterología y Departamento de Patología Clínica, Hospital Universitario Dr. José Eleuterio González, Universidad Autónoma de Nuevo Leon, Av. Madero y Gonzalitos S/N, Mitras Centro, Monterrey, NL 64220, Mexico; E-Mail: elvira_garza_gzz@yahoo.com

$\dagger$ These authors contributed equally to this work.

* Author to whom correspondence should be addressed; E-Mail: olmo@usal.es;

Tel.: +34-923-294-500 (ext. 1825); Fax: +34-923-294-521.

Academic Editor: Derek J. McPhee

Received: 2 February 2015 / Accepted: 13 April 2015 / Published: 21 April 2015

\begin{abstract}
Seventeen new derivatives of the natural diterpene leubethanol, including some potential pro-drugs, with changes in the functionality of the aliphatic chain or modifications of aromatic ring and the phenolic group, were synthesized and tested in vitro by the MABA technique for their activity against the H37Rv strain of Mycobacterium tuberculosis. Some compounds showed antimycobacterial selectivity indices higher than leubethanol.
\end{abstract}

Keywords: serrulatane derivatives; leubethanol; semi-synthesis; in vitro antimycobacterial activity; cytotoxicity assay 


\section{Introduction}

Tuberculosis (TB) caused by Mycobacterium tuberculosis (Mtb) remains a worldwide health problem. According to the latest report from the World Health Organization (WHO), the number of people suffering from TB in 2013 was 9.0 million and approximately 1.5 million people died from the disease [1]. Moreover, Mtb is highly infectious; it is reported that about one third of the world's population is latently infected, and that $10 \%$ of this population will develop active disease. A further significant problem is the association with HIV infection, from 1.5 million deaths caused by TB in 2013, 0.36 million deaths were in HIV positive people. Therefore, TB-HIV co-infection is a major public health problem [1].

The current first line drugs for TB treatment (isoniazid (INH), rifampicin (RIF), pyrazinamide and ethambutol) were discovered decades ago and are increasingly becoming less useful due to emerging multidrug-resistant (MDR), extended (XDR) or extremely (XXDR) resistant strains [2]. There were an estimate of 480,000 new cases of multidrug-resistant tuberculosis (MDR-TB) and 170,000 MDR-TB-related deaths. Treatment of MDR-TB disease requires high resources and at least the administration of RIF and INH in combination with second-line drugs. Second line drugs are more expensive, more toxic, and less effective than drugs used in standard therapy [3]. These facts have motivated the search for new drugs and treatment strategies. New drug candidates should shorten conventional chemotherapy and be effective against MDR-TB.

Natural products have played an important role in the discovery of new drugs, as is the chemotherapy of tuberculosis [4,5], with the discovery of streptomycin, capreomycin, cycloserine, or development of rifamycin derivatives. Now, there is a re-emerging interest in natural products as novel template for the development of new drugs and particularly suitable as antibacterial leads [6-8]. Compounds bearing a serrulatane skeleton have been reported as good antimycobacterial agents [9-11].

Waksman et al. isolated leubethanol (Leub), a natural serrulatane diterpenoid, from Leucophyllum frutescens methanolic extracts [10] and introduced different modifications on the skeleton to improve antimycobacterial activity [12]. Taking into account previous results of the research group on leubethanol structure modification related to antimycobacterial activity [12] and the information of similar structures reported in the literature $[9,11]$, we intended to explore in the present study new possibilities to obtain better antimycobacterial compounds by introducing a glycosylated fragment on Leub phenolic hydroxyl, substitutions on the aromatic ring A, and new side-chain functionalizations (Figure 1).
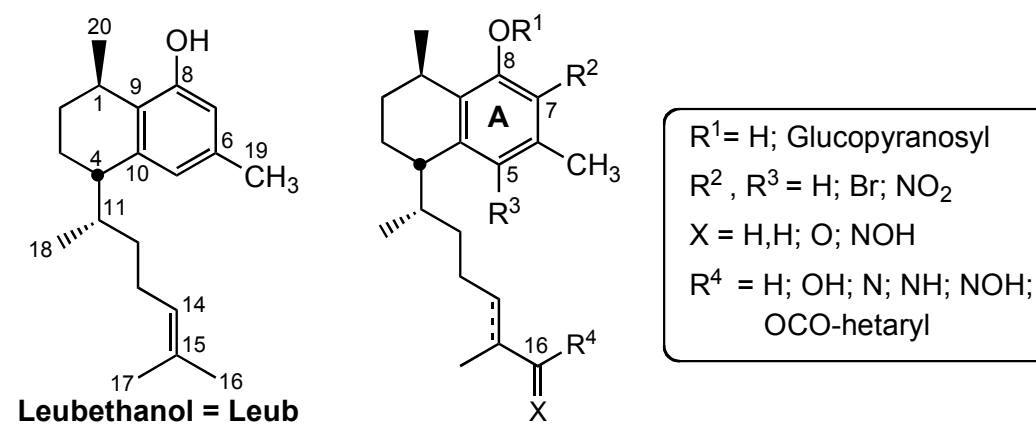

Figure 1. Leubethanol modifications on ring A and the alkyl side chain. 


\section{Results and Discussion}

\subsection{Chemistry}

Leubethanol 8-O- $\beta$-D-glucopyranosyl derivative 1 was obtained with Schmidt trichloroacetimidate as glucosyl donor. Thus, Leub was treated with 2,3,4,6-tetra- $O$-acetyl- $\alpha$-D-glucopyranosyl trichloroacetimidate [13] and $\mathrm{BF}_{3} \cdot \mathrm{OEt}$ as Lewis acid catalyst in dichloromethane [14] to give the 8 - $O$-(2,3,4,6-tetra- $O$-acetyl- $\beta$-D-glucopyranosyl)leubethanol as the only adduct in $80 \%$ yield. When acetonitrile was used as reaction solvent instead of dichloromethane the reaction did not proceed [15]. In previous attempts to obtain the tetra- $O$-acetyl-glucopyranosyl Leub derivative by using 2,3,4,6-tetra- $O$-acetyl- $\alpha$-D-glucopyranosyl bromide with potassium carbonate in chloroform [16], silver carbonate in pyridine [17], or transfer-phase catalysis with tetrabutylammonium bromide [18] no glycosidation product was obtained.

Inversion of the anomeric carbon configuration of the $8-O-\beta-\mathrm{D}-\mathrm{glucopyranosyl}$ Leub derivative was established by a study of the H-1' coupling constant, with a value of $3.7 \mathrm{~Hz}$ in the glucopyranosyl trichloroacetimidate and of $7.9 \mathrm{~Hz}$ in the Leub aduct. Afterwards, the obtained Leub derivative was treated with sodium ethoxide in ethanol to provide compound 1 in $52 \%$ yield. Unequivocal structural assignment was achieved by 2D-NMR experiments ( $\left.{ }^{1} \mathrm{H},{ }^{1} \mathrm{H}-\mathrm{COSY}, \mathrm{HMQC}, \mathrm{HMBC}\right)$.

We introduced electron withdrawing groups $\left(\mathrm{NO}_{2}, \mathrm{Br}\right)$ on ring A. Leub treatment with $65 \% \mathrm{HNO}_{3}$ gave a mixture of 7-nitro and 5-nitro derivatives, (compounds 2 and 3, respectively) in 1.5:1.0 ratio. The unambiguous structural assignment of the nitrated derivatives was established by NOE experiments. Irradiation of the proton at $6.50 \mathrm{ppm}$ on compound $\mathbf{2}$ showed a NOE effect on two of the methyls, the aromatic methyl at $2.21 \mathrm{ppm}$ and the methyl doublet on the aliphatic chain at $0.83 \mathrm{ppm}$. On the other hand, irradiation of the proton at $6.63 \mathrm{ppm}$ on compound 3 showed a NOE effect on the hydroxylic proton at $11.27 \mathrm{ppm}$ and on the aromatic methyl at $2.57 \mathrm{ppm}$. The aliphatic double bond of Leub was hydrogenated with $\mathrm{H}_{2}$ in the presence of Pd-C catalyst, and the resulting 14,15-dihydroleubethanol treated with $N$-bromosuccinimide (NBS) to provide 7-bromoleubethanol (4) in 67\% yield (Scheme 1). As just mentioned in the nitro derivatives, the bromine atom introduction at Leub position 7 was unequivocally established by NOE experiments.
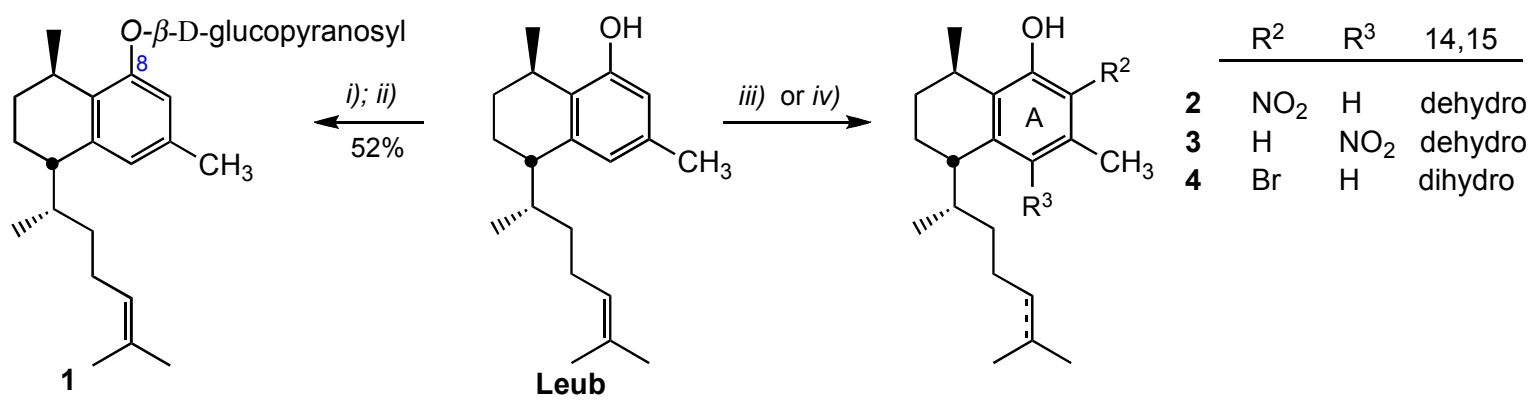

i) 2,3,4,6-Tetra- $O$-acetyl- $\alpha$-D-glucopyranosyl trichloroacetimidate, $\mathrm{BF}_{3} \cdot \mathrm{OEt} / \mathrm{CH}_{2} \mathrm{Cl}_{2}$. ii) EtONa / EtOH. iii) $60 \% \mathrm{HNO}_{3}$. iv) $\mathrm{NBS} / \mathrm{CCl}_{4}$.

Scheme 1. Modifications of leubethanol on the phenolic hydroxyl and aromatic ring A.

Then, some modifications on the side chain were performed (Scheme 2). First, we obtained the allylic alcohol 5 and the $\alpha, \beta$-unsaturated aldehyde 6 (in 2.2:1 proportion) by Leub treatment with selenium 
dioxide. Treatment of compound 5 under Sharpless asymmetric epoxidation conditions (with L-(+)diethytartrate) gave the corresponding $\alpha$-oxirane derivative 7 in $65 \%$ yield and $\sim 91 \%$ ee. The allylic alcohol 5 was condensed with pyrazinecarboxylic acid in the presence of $N, N$-dicyclohexyl-carbodiimide (DCC) as coupling reagent to give the pyrazine ester derivative $\mathbf{8}$ in 53\% yield. Compound $\mathbf{8}$ showed ${ }^{1} \mathrm{H}-\mathrm{NMR}$ signals at $9.29 \mathrm{ppm}(1 \mathrm{H}, \mathrm{d}, J=1.6 \mathrm{~Hz}), 8.75 \mathrm{ppm}(1 \mathrm{H}, \mathrm{d}, J=2.4 \mathrm{~Hz})$ and $8.73(1 \mathrm{H}, \mathrm{dd}, J=2.4$; $1.6 \mathrm{~Hz}$ ) of the pyrazine ring. Attempts to obtain other esters by treatment with 2-amino-isonicotinic acid or with 6-aminopyridine-3-carboxylic acid reaction did not progress, even by changing the coupling reagent (1-ethyl-3-(3-dimethylaminopropyl)carbodiimide, EDCI), the reaction solvent, or by increasing reaction time or the temperature.

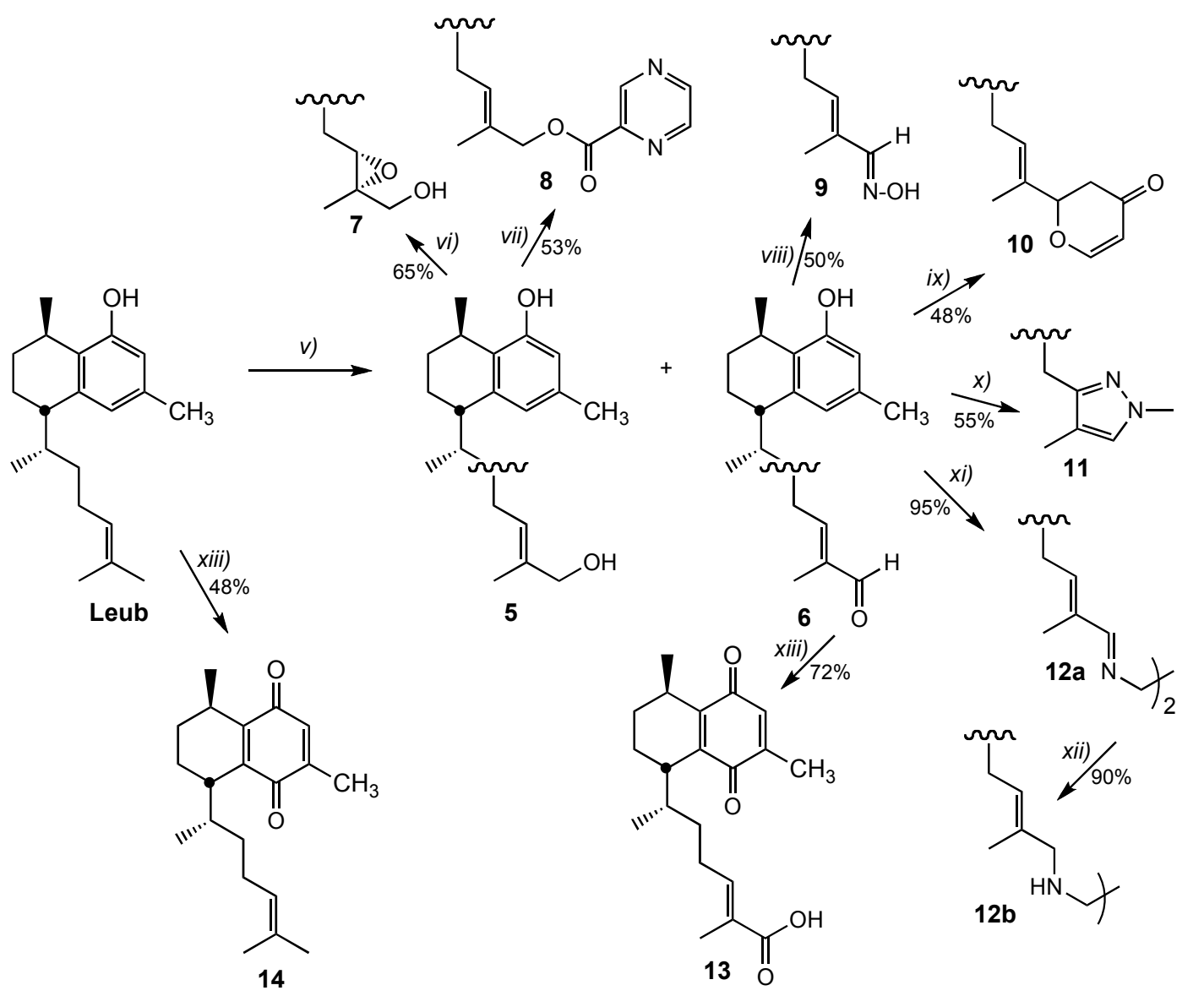

v) $\mathrm{SeO}_{2}$ / EtOH. vi) . vii) $\mathrm{L}(+)-\mathrm{DET}, \mathrm{Ti}\left(\mathrm{O} \mathrm{Pr}_{4} /{ }^{t} \mathrm{BuOOH}\right.$. vii) Pyrazinecarboxylic acid / $\mathrm{DCC} / \mathrm{CH}_{2} \mathrm{Cl}_{2}$. viii) $\mathrm{NH}_{2} \mathrm{OH} . \mathrm{HCl} / \mathrm{CCl}_{4} / \mathrm{Pyr}$. ix) trans-methyl-trimethylsilyloxy-1,3-butadiene / $\mathrm{BF}_{3}$. $\mathrm{Et}_{2} \mathrm{O}$. x) $\mathrm{H}_{2} \mathrm{NNHCH}_{3}$. xi) $\mathrm{H}_{2} \mathrm{~N}\left(\mathrm{CH}_{2}\right)_{2} \mathrm{NH}_{2}$, toluene. xii) $\mathrm{NaBH}_{4} / \mathrm{MeOH}$. xiii) $\mathrm{NaClO}_{2},{ }^{t} \mathrm{BuOH}$.

Scheme 2. Synthesis of leubethanol derivatives modified at the side chain.

Furthermore, the $\alpha, \beta$-unsaturated aldehyde 6 was used to obtain compounds 9-13. Treatment of compound $\mathbf{6}$ with hydroxylamine hydrochloride in dichloromethane/pyridine provided the hydroxyimine 9, which showed two singlet signals at 7.66 and $8.09 \mathrm{ppm}$ in its ${ }^{1} \mathrm{H}-\mathrm{NMR}$ for the hydroxyimine group. The dihydropyranone $\mathbf{1 0}$ was obtained by reaction of $\mathbf{6}$ with trans-methoxy-trimethylsilyloxy-1,3butadiene in the presence of boron trifluoride diethyl ether with 48\% yield [19]. Compound 10 was completely characterized by 2D-NMR experiments $\left({ }^{1} \mathrm{H},{ }^{1} \mathrm{H}-\mathrm{COSY}\right.$, HMQC, HMBC). The dihydropyranone fragment showed the ${ }^{1} \mathrm{H}-\mathrm{NMR}$ signals at $4.69 \mathrm{ppm}(1 \mathrm{H}, \mathrm{dd}, J=14.5,2.4 \mathrm{~Hz}, \mathrm{H}-16$; 
$84.5 \mathrm{ppm}$ in the $\left.{ }^{13} \mathrm{C}-\mathrm{NMR}\right), 2.73 \mathrm{ppm}(1 \mathrm{H}, \mathrm{dd}, J=16.7,14.5 \mathrm{~Hz})$ and $2.35 \mathrm{ppm}(1 \mathrm{H}, \mathrm{m})$ of the methylene $(\mathrm{H}-24)$ and at $7.39(1 \mathrm{H}, \mathrm{d}, J=7.1 \mathrm{~Hz}, \mathrm{H}-21)$ and $5.52 \mathrm{ppm}(1 \mathrm{H}, \mathrm{d}, J=7.1 \mathrm{~Hz}, \mathrm{H}-22)$ of the olefinic protons. Treatment of $\mathbf{6}$ with methylhydrazine in 2-propanol under refluxing conditions gave the pyrazole 11 with 55\% yield [20]. Compound 11 showed in its ${ }^{1} \mathrm{H}-\mathrm{NMR}$ a one olefinic proton singlet at $7.00 \mathrm{ppm}(\mathrm{H}-16)$ and a methyl at $3.75 \mathrm{ppm}$ of the $\mathrm{CH}_{3}-\mathrm{N}$. Two moles of $\mathbf{6}$ were treated with one mole of ethylenediamine in anhydrous toluene and a large excess of anhydrous sodium sulfate at room temperature to give a diimine 12a, which was reacted with sodium borohydride in ethanol to provide the ethylenediamine $\mathbf{1 2 b}$, in a total yield of $86 \%$. Finally, compound $\mathbf{6}$ was treated with sodium chlorite [21] to oxidize the aldehyde to an acid. The additional oxidation on the aromatic ring was observed. Compound 13 showed a quinone fragment with chemical shifts at 188.4 and 187.1 ppm of carbons C-5 and C-8, respectively, in addition to a new carbonyl at $173.00 \mathrm{ppm}$ of the acid group. Only one aromatic proton was appreciated in ${ }^{1} \mathrm{H}-\mathrm{NMR}$ at $6.52 \mathrm{ppm}$. To compare the influence of the quinone fragment on the antimycobacterial activity, we decided to obtain the quinone of Leub, compound $\mathbf{1 4 .}$

Promising antimycobacterial activity against $M t b \mathrm{H} 37 \mathrm{Rv}$ strain has been reported in the literature [9] for pseudopteroxazole and its analogue seco-pseudopteroxazole (MIC values of $97 \%$ and $66 \%$ mycocacterial growth inhibition at $12.5 \mu \mathrm{g} / \mathrm{mL}$ ). Then, we decided to obtain the tricyclic diterpene analogue of Leub (Scheme 3).
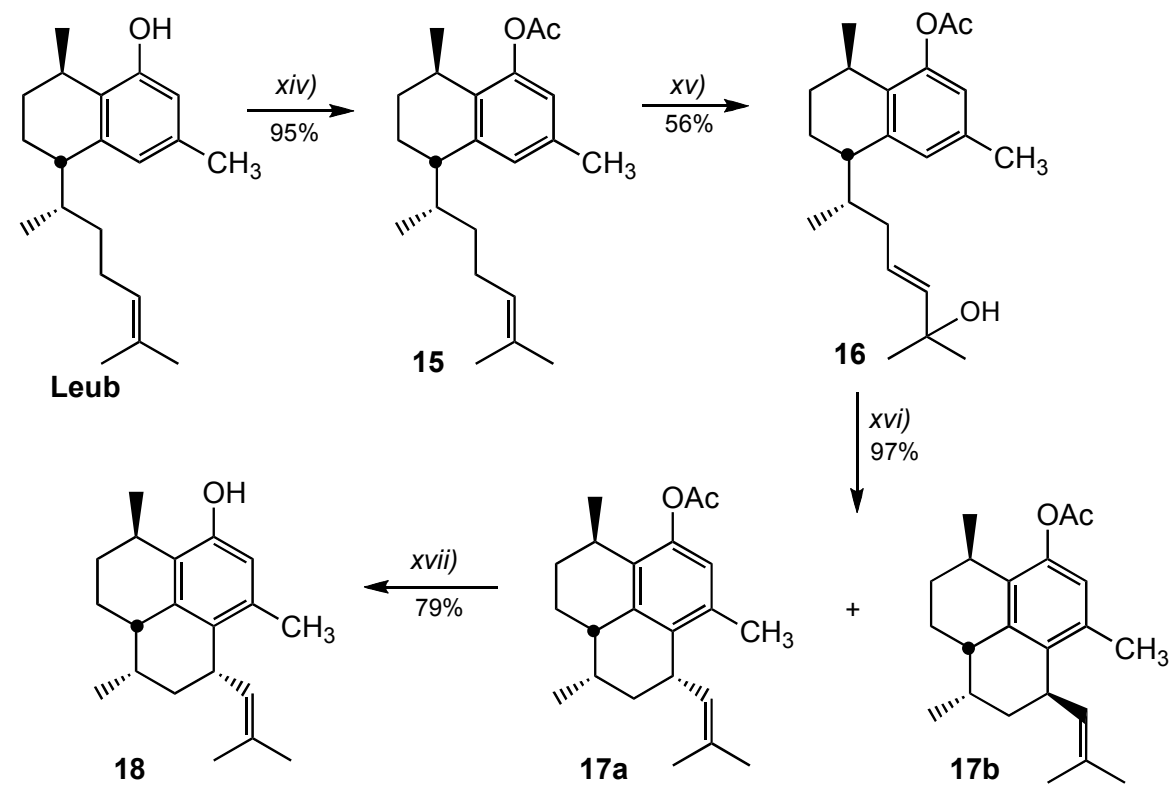

xiv) $\mathrm{Ac}_{2} \mathrm{O} /$ Pyr. xv) a) Diphenyselenide $/ \mathrm{CH}_{2} \mathrm{Cl}_{2}$, b) ${ }^{t} \mathrm{BuOOH}$. xvi) $\mathrm{CH}_{3} \mathrm{SO}_{3} \mathrm{H} / \mathrm{TEA}$. $x$ vii) $\mathrm{KOH} / \mathrm{MeOH}$

Scheme 3. Synthesis of the tricyclic derivative 18 from leubethanol.

The phenol group was protected as an acetate by reaction of Leub with acetate anhydride in the presence of pyridine. Compound 15 showed a methyl group at $2.12 \mathrm{ppm}$ in ${ }^{1} \mathrm{H}-\mathrm{NMR}$ and two acetyl group signals at 169.7 and $21.2 \mathrm{ppm}$ in the ${ }^{13} \mathrm{C}-\mathrm{NMR}$. Then, the allylic alcohol 16 was obtained in $56 \%$ yield by compound 15 treatment with phenylseleninic acid (obtained in situ from diphenyl deselenide and hydrogen peroxide) followed by tert-butyl-hydroperoxide. Compound $\mathbf{1 6}$ displayed two singlet methyl groups at 1.22 and $1.23 \mathrm{ppm}$, and two olefinic protons at $5.30 \mathrm{ppm}$ as a multiplet, and at $5.51 \mathrm{ppm}$ as a doublet $(J=15.8 \mathrm{~Hz})$ in the ${ }^{1} \mathrm{H}-\mathrm{NMR}$. Cyclization of compound $\mathbf{1 6}$ was achieved using 
methanesulfonic acid in $\mathrm{CH}_{2} \mathrm{Cl}_{2}$ at $-40{ }^{\circ} \mathrm{C}$. Although the cyclization proceeded quantitatively, the product was a mixture of diastereomers 17a and $\mathbf{1 7} \mathbf{b}$ in a ratio of about 2:1. Compound 17a could be separated by silica gel chromatography, while compound $\mathbf{1 7 \mathbf { b }}$ was obtained as a mixture of $\mathbf{1 7} \mathbf{a}$ and $\mathbf{1 7 b}$. In the case of $\mathbf{1 7 a}$, the vinyl proton attached to $\mathrm{C}(14)$ appeared at $\delta 4.99$ as a broad doublet, $J=9.2 \mathrm{~Hz}$ while in $\mathbf{1 7 b}$ it was observed at $\delta 5.14$ (doublet, $J=9.2 \mathrm{~Hz}$ ). Compound 17a saponification with $\mathrm{KOH} / \mathrm{MeOH}$ finally gave the phenol derivative $\mathbf{1 8}$. The overall yield from Leub to $\mathbf{1 8}$ was $41 \%$.

\subsection{Antimycobacterial Activity}

The anti-MTB activity was assessed in vitro against the H37Rv strain (ATTC 27294) [22] susceptible to all SIREP anti-TB drugs, according to a modified Microplate Alamar Blue Assay (MABA) [23]. Ethambutol (EMB) was used as the reference drug and the assays were performed by triplicate independent experiments. Cytotoxicity on Vero cells [24] was also measured for those compounds with an appreciable in vitro anti-MTB effect.

The in vitro antimycobacterial results of the Leub and seventten derivatives are shown in Table 1. The introduction of a glycoside fragment on the phenolic group induces the loss of the activity. We knew that the introduction of acyl or alkyl fragments at this position were not convenient for the activity, but we expected that the introduction of other hydroxyl groups (as is a glycoside) would not modify the activity results, so this indicates that phenol acidic properties are crucial for good activity. Substitutions at position 5 or 7 on Leub were also relevant for the antimycobacterial activity. We had previously found that the introduction of aromatic substituents on position 5 maintained Leub activity [12]. Taken into account the antimycobacterial activity results found for the pseudopterosins [9], compounds with an oxazole between positions 7 and 8 of the serrulatane skeleton, we expected to see good activity results for compounds substituted at position 7, like compounds 2 and 4, but they did not show activity. The antimycobacterial activity of compound $\mathbf{3}$ was a slightly lower than that of Leub, with small increase in the selectivity index. We planned to obtain the bromine derivative at position 5 to compare the antimycobacterial activity with compound $\mathbf{3}$, for this we had to previously protect the phenol group with a bulky group to force the introduction of the bromine at position 5, but in the process of removing the protecting group we got a mixture of compounds of difficult separation. As we indicated in the previous work functionalization of the C-16 methyl, compounds $\mathbf{5}$ and $\mathbf{6}$ showed similar potency and selectivity index to the natural compound leubethanol,

Modifications of the aliphatic chain by introduction of an oxirane on the 14,15-double bond, (compound 7), or modifications on the alcohol or aldehyde functions, pyrazine ester $\mathbf{8}$, the hydroxyimine 9, or the heterocyclic compounds $\mathbf{1 0}$ and $\mathbf{1 1}$ led to the loss of activity. Only Leub dimer 12a, tricyclic derivative 18 and especially the ethylenediamine 12b maintained the antimycobacterial activity. Regarding the Vero cells/Mtb selectivity, compounds 3, 5, 6 and $\mathbf{1 8}$ showed similar selectivity to leubethanol, and compound $\mathbf{1 2 b}$ twice as much as leubethanol. 
Table 1. Antimycobacterial activity, cytotoxicity and selectivity index of leubethanol derivatives.
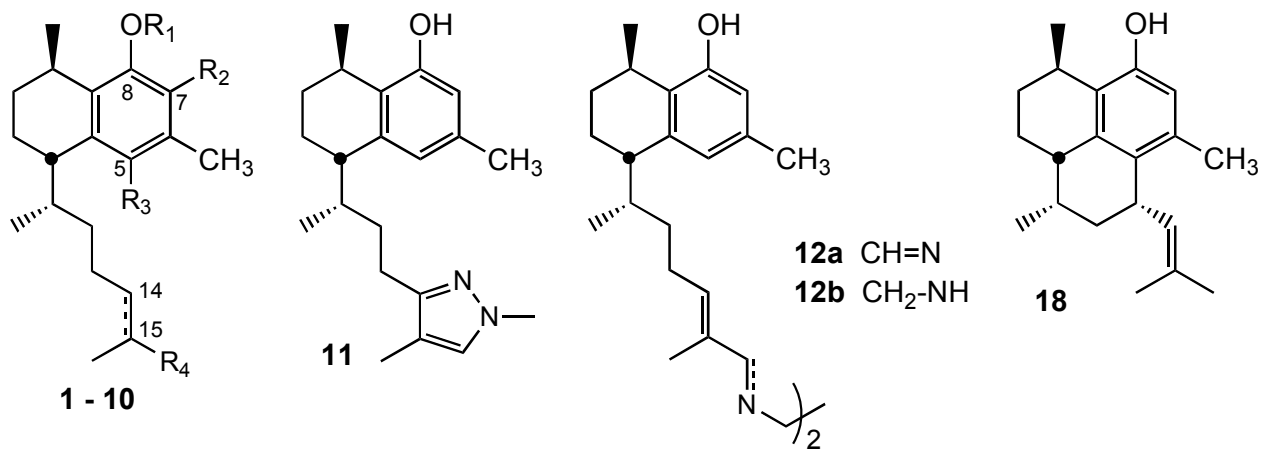

\begin{tabular}{|c|c|c|c|c|c|c|c|c|}
\hline Comp. & $14,15-$ & $\mathbf{R}_{\mathbf{1}}$ & $\mathbf{R}_{\mathbf{2}}$ & $\mathbf{R}_{\mathbf{3}}$ & $\mathbf{R}_{4}$ & $\begin{array}{c}\text { MTB } \mathrm{H}_{37} \mathrm{Rv} \\
\text { MIC }(\mu \mathrm{M})\end{array}$ & $\begin{array}{l}\text { Vero Cells } \\
\mathrm{CC}_{50}(\mu \mathrm{M})\end{array}$ & $\begin{array}{l}\text { Selectivity } \\
\text { Index (SI) }\end{array}$ \\
\hline Leub & $-\mathrm{CH}=\mathrm{C}$ & $\mathrm{H}$ & $\mathrm{H}$ & $\mathrm{H}$ & $\mathrm{CH}_{3}$ & 25.1 & 123 & 4.9 \\
\hline 1 & $-\mathrm{CH}=\mathrm{C}$ & Gluc & $\mathrm{H}$ & $\mathrm{H}$ & $\mathrm{H}$ & $>200$ & nd & -- \\
\hline 2 & $-\mathrm{CH}=\mathrm{C}$ & $\mathrm{H}$ & $\mathrm{NO}_{2}$ & $\mathrm{H}$ & $\mathrm{CH}_{3}$ & $>200$ & nd & -- \\
\hline 3 & $-\mathrm{CH}=\mathrm{C}$ & $\mathrm{H}$ & $\mathrm{H}$ & $\mathrm{NO}_{2}$ & $\mathrm{CH}_{3}$ & 47.2 & 251 & 5.3 \\
\hline 4 & $-\mathrm{CH}_{2}-\mathrm{CH}-$ & $\mathrm{H}$ & $\mathrm{Br}$ & $\mathrm{H}$ & $\mathrm{CH}_{3}$ & $>200$ & nd & -- \\
\hline 5 & $-\mathrm{CH}=\mathrm{C}$ & $\mathrm{H}$ & $\mathrm{H}$ & $\mathrm{H}$ & $\mathrm{CH}_{2} \mathrm{OH}$ & 25.8 & 132 & 5.1 \\
\hline 6 & $-\mathrm{CH}=\mathrm{C}$ & $\mathrm{H}$ & $\mathrm{H}$ & $\mathrm{H}$ & $\mathrm{CHO}$ & 25.8 & 116 & 4.5 \\
\hline 7 & $\mathrm{HC}^{\prime}$ & $\mathrm{H}$ & $\mathrm{H}$ & $\mathrm{H}$ & $\mathrm{CH}_{2} \mathrm{OH}$ & $>200$ & nd & -- \\
\hline 8 & $-\mathrm{CH}=\mathrm{C}$ & $\mathrm{H}$ & $\mathrm{H}$ & $\mathrm{H}$ & $\mathrm{CH}_{2} \mathrm{OCOC}_{4} \mathrm{H}_{3} \mathrm{~N}_{2}$ & $>200$ & nd & -- \\
\hline 9 & $-\mathrm{CH}=\mathrm{C}$ & $\mathrm{H}$ & $\mathrm{H}$ & $\mathrm{H}$ & $\mathrm{C}=\mathrm{N}-\mathrm{OH}$ & $>200$ & nd & -- \\
\hline 10 & $-\mathrm{CH}=\mathrm{C}$ ไ & $\mathrm{H}$ & $\mathrm{H}$ & $\mathrm{H}$ & & $>200$ & nd & -- \\
\hline 11 & & & & & & $>200$ & nd & -- \\
\hline $12 \mathrm{a}$ & & & & & & 100.1 & nd & -- \\
\hline $12 b$ & & & & & & 24.8 & 215 & 8.7 \\
\hline 13 & & & & & & $>200$ & nd & -- \\
\hline 14 & & & & & & $>200$ & nd & -- \\
\hline 18 & & & & & & 55.1 & 173 & 3.1 \\
\hline EMB & & & & & & 7.5 & $>500$ & $>67$ \\
\hline
\end{tabular}

$\mathrm{MIC}$ and $\mathrm{CC}_{50}$ : rounded media values of three experiments; $\mathrm{nd}=$ no determined; --: not calculated; Selectivity index calculated by the equation: $\mathrm{SI}=\mathrm{CC}_{50}(\mathrm{Vero}) / \mathrm{MIC}\left(\mathrm{H}_{37} \mathrm{Rv}\right) . \mathrm{EMB}=$ Ethambutol. Gluc $=\beta$-D-glucopyranosyl.

\section{Experimental Section}

\subsection{General Information}

All commercial chemicals and solvents used were reagent grade. Flash column chromatography was done using Merck Silica Gel $60(0.04-0.063 \mathrm{~mm})$. Reactions were monitored by TLC using Merck $60 \mathrm{~F}_{254}$ silica gel plates. Compounds were detected visually under UV irradiation $(254 \mathrm{~nm})$ and by spraying with sulfuric acid and phosphomolybdic acid reagents followed by heating at $100{ }^{\circ} \mathrm{C} .{ }^{1} \mathrm{H}-\mathrm{NMR}$ 
and ${ }^{13} \mathrm{C}$-NMR spectra were obtained with a Bruker AC 200 spectrometer $(200$ and $50.3 \mathrm{MHz}$, respectively). Chemical shifts were recorded in parts per million (ppm, $\delta$ ) and were reported relative to the solvent peak or TMS. High resolution mass spectra (HRMS) were measured with a QSTAR XL quadrupole time-of-flight mass spectrometer, by direct injection on the sample dissolved in $\mathrm{MeOH}$ and Ionization voltage of $5500 \mathrm{~V}$. Infrared (IR) spectra were measured on a Nicolet Impact 410 spectrophotometer. The absorbances were measured with a Bio-Rad Benchmark model microplate reader. Middlebrook $7 \mathrm{H} 9$ broth medium was obtained from Difco ${ }^{\circledR}$ (Becton Dickinson and Co., Sparks, MD, USA) resazurin from Probiotek ${ }^{\circledR}$ (Hayward, CA, USA), and $0.45 \mu \mathrm{m}$ pore size, $13 \mathrm{~mm}$ diameter PTFE from Millipore Millex ${ }^{\circledR}$ (Millipore Co., Bedford, MA, USA) Isoniazid, rifampicin, penicillin, streptomycin, and MTT were obtained from Sigma ${ }^{\circledR}$ (St. Louis, MO, USA) and fetal bovine serum from Hyclone $^{\circledR}$ (Logan, UT, USA).

\subsection{Chemistry}

\subsubsection{Preparation of $8-O-(2,3,4,6$-Tetra- $O$-acetyl- $\beta$-D-glucopyranosyl) leubethanol}

To a stirred solution of leubethanol $(112 \mathrm{mg}, 0.40 \mathrm{mmol})$ in dry $\mathrm{CH}_{2} \mathrm{Cl}_{2}(5 \mathrm{~mL})$ at $-20{ }^{\circ} \mathrm{C}, \mathrm{BF}_{3} \cdot \mathrm{Et}_{2} \mathrm{O}$ $(75 \mu \mathrm{L}, 0.60 \mathrm{mmol})$ with a syringe was added. Immediately, the suspension turned into a light-yellow solution. The mixture was stirred for $45 \mathrm{~min}$ and then, a solution of 2,3,4,6-tetra- $O$-acetyl- $\alpha$-Dglucopyranosyl trichloroacetimidate $(292 \mathrm{mg}, 0.59 \mathrm{mmol})$, recently obtained, in $\mathrm{CH}_{2} \mathrm{Cl}_{2}(2 \mathrm{~mL})$ was added. The reaction was maintained for $4 \mathrm{~h}$ at room temperature. After that, the solution was diluted with $\mathrm{CH}_{2} \mathrm{Cl}_{2}$ and was washed with $10 \% \mathrm{NaHCO}_{3}$, brine, water and dried over sodium sulphate. The organic layer was concentrated to give an oil, that was purified by column chromatography with $n$-hexane/ethyl acetate $(95: 5)$ as eluent to give $207 \mathrm{mg}(80 \%)$ of 8 - $O$-(2,3,4,6-tetra- $O$-acetyl- $\beta$-Dglucopyranosyl) leubethanol. IR: 2956, 2928, 2870, 1755, 1696, 1612, 1606, 1575, 1516, 1450, 1378, 1226, 1108, 1043, 832, $750 \mathrm{~cm}^{-1}$; ${ }^{1} \mathrm{H}-\mathrm{NMR}\left(\mathrm{CDCl}_{3}\right): \delta 0.95(3 \mathrm{H}, \mathrm{d}, J=6.8 \mathrm{~Hz}), 1.11(3 \mathrm{H}, \mathrm{d}$, $J=5.7 \mathrm{~Hz}), 1.1-1.3(2 \mathrm{H}, \mathrm{m}), 1.54(3 \mathrm{H}, \mathrm{s}), 1.65,(3 \mathrm{H}, \mathrm{s}), 1.16-2.0(7 \mathrm{H}, \mathrm{m}), 2.03(3 \mathrm{H}, \mathrm{s}), 2.04(3 \mathrm{H}, \mathrm{s})$, $2.05(3 \mathrm{H}, \mathrm{s}), 2.09(3 \mathrm{H}, \mathrm{s}), 2.26(3 \mathrm{H}, \mathrm{s}), 2.53(1 \mathrm{H}, \mathrm{m}), 2.88(1 \mathrm{H}, \mathrm{m}), 3.89(1 \mathrm{H}, \mathrm{m}), 4.21(2 \mathrm{H}, \mathrm{m}), 5.00$ $(1 \mathrm{H}, \mathrm{d}, J=6.8), 5.15(1 \mathrm{H}, \mathrm{t}, J=8.8 \mathrm{~Hz}), 5.33(3 \mathrm{H}, \mathrm{m}), 6.71(1 \mathrm{H}, \mathrm{s}), 6.72(1 \mathrm{H}, \mathrm{s}) ;{ }^{13} \mathrm{C}-\mathrm{NMR}\left(\mathrm{CDCl}_{3}\right): \delta$ 17.7, 18.8, 19.3, 20.7, 21.6, 22.7 (4C), 25.8, 26.2, 26.8, 27.5, 33.2, 42.4, 37.7, 62.4, 68.6, 71.2, 71.9, 72.9, 99.3, 113.8, 124.9 (2C), 129.9, 131.1, 134.8, 140.9, 154.6; 169.3, 169.6, 170.4, 170.7; HRMS $\left(\mathrm{ESI}^{+}\right.$) for $\mathrm{C}_{34} \mathrm{H}_{48} \mathrm{O}_{10} \mathrm{Na}[\mathrm{M}+\mathrm{Na}]^{+}$calcd. 639.3145; found 639.3110 .

\subsubsection{Preparation of 8-O-( $\beta$-D-Glucopyranosyl)leubethanol (1)}

2,3,4,6-Tetra- $O$-acetyl- $\beta$-D-glucopyranosyl leubethanol (160 $\mathrm{mg}, 0.25 \mathrm{mmol}$ ) was dissolved in dry $\mathrm{EtOH}(5 \mathrm{~mL})$ and a solution of sodium ethoxide $(28 \mathrm{mg} \mathrm{Na}, 1.25 \mathrm{mmol})$ in EtOH was added. After stirring the mixture at room temperature for $2 \mathrm{~h}$ the reaction was completed. The solution was taken to dryness to obtain a residue that was purified by column chromatography with $\mathrm{CH}_{2} \mathrm{Cl}_{2} / \mathrm{MeOH}(8: 2)$ as eluent to give $58 \mathrm{mg}$ (52\%) of compound 1. IR: 3412, 2923, 2862, 1652, 1612, 1575, 1458, 1376, 1268, 1075, $841 \mathrm{~cm}^{-1}$; ${ }^{1} \mathrm{H}-\mathrm{NMR}\left(400 \mathrm{MHz}, \mathrm{CDCl}_{3}\right): \delta 0.95(3 \mathrm{H}, \mathrm{d}, J=6.7 \mathrm{~Hz}), 0.96-1.30(4 \mathrm{H}, \mathrm{m}), 1.30(3 \mathrm{H}$, $\mathrm{d}, J=6.8 \mathrm{~Hz}), 1.51(3 \mathrm{H}, \mathrm{s}), 1.60-2.0(8 \mathrm{H}, \mathrm{m}), 1.62(3 \mathrm{H}, \mathrm{s}), 2.24(3 \mathrm{H}, \mathrm{s}), 2.57(1 \mathrm{H}, \mathrm{m}), 3.28(1 \mathrm{H}, \mathrm{m})$, $3.32(1 \mathrm{H}, \mathrm{m}), 3.41(1 \mathrm{H}, \mathrm{m}), 3.49(1 \mathrm{H}, \mathrm{m}), 3.70(1 \mathrm{H}, \mathrm{dd}, J=12.1,5.8), 3.89(1 \mathrm{H}, \mathrm{dd}, J=12.1,2.0), 4.87$ 
$(1 \mathrm{H}, \mathrm{d}, J=7.3 \mathrm{~Hz}), 4.93(1 \mathrm{H}, \mathrm{t}, J=6.8 \mathrm{~Hz}), 6.63(1 \mathrm{H}, \mathrm{s}), 6.79(1 \mathrm{H}, \mathrm{s}) ;{ }^{13} \mathrm{C}-\mathrm{NMR}\left(50.3 \mathrm{MHz}, \mathrm{CDCl}_{3}\right): \delta$ $17.7,19.1,20.3,21.6,22.2,25.9,27.4,27.5,28.6,34.6,39.5,43.7,62.7,71.6,78.1,78.4,75.2,102.2$, 113.7, 124.6, 125.9, 132.5, 132.0, 136.0, 141.2, 156.6; HRMS $\left(\mathrm{ESI}^{+}\right)$for $\mathrm{C}_{26} \mathrm{H}_{41} \mathrm{O} 6[\mathrm{M}+\mathrm{H}]^{+}$calcd. 449.2903; found 449.2937 .

\subsubsection{Preparation of 7-Nitroleubethanol (2) and 5-Nitroleubethanol (3)}

To a solution of leubethanol (56 mg, $0.19 \mathrm{mmol})$ in $n$-hexane ( $2 \mathrm{~mL}) 65 \% \mathrm{HNO}_{3}(16 \mu \mathrm{L}, 0.23 \mathrm{mmol})$ was added and the mixture stirred for $8 \mathrm{~h}$. Then, ethyl acetate $(30 \mathrm{~mL})$ was added and the organic layer was washed with $5 \% \mathrm{NaHCO}_{3}$, water and dried over $\mathrm{Na}_{2} \mathrm{SO}_{4}$. The solvent was removed under vacuum to provide a crude $(60 \mathrm{mg})$, that was purified by silica flash chromatography using $n$-hexane/ethyl acetate (95:5) as eluent, to give $23 \mathrm{mg} \mathrm{(37 \% )}$ of 7-nitroleubethanol (2) and $16 \mathrm{mg} \mathrm{(26 \% )}$ of 5-nitroleubethanol (3).

Compound 2. IR: 3450, 2959, 2927, 2870, 1606, 1575, 1516, 1453, 1352, 1239, 1181, 1128, $1052 \mathrm{~cm}^{-1}$; ${ }^{1} \mathrm{H}-\mathrm{NMR}\left(\mathrm{CDCl}_{3}\right): \delta 0.83(3 \mathrm{H}, \mathrm{d}, J=6.8 \mathrm{~Hz}), 1.18(3 \mathrm{H}, \mathrm{d}, J=6.8 \mathrm{~Hz}), 1.3-1.1(2 \mathrm{H}, \mathrm{m}), 1.52(3 \mathrm{H}, \mathrm{s})$, $1.65(3 \mathrm{H}, \mathrm{s}), 2.0-1.6(7 \mathrm{H}, \mathrm{m}), 2.21(3 \mathrm{H}, \mathrm{s}), 3.12(2 \mathrm{H}, \mathrm{m}), 4.93(1 \mathrm{H}, \mathrm{t}, J=6.8 \mathrm{~Hz}), 5.37(1 \mathrm{H}, \mathrm{br} \mathrm{s}), 6.50$ $(1 \mathrm{H}, \mathrm{s}) ;{ }^{13} \mathrm{C}-\mathrm{NMR}\left(\mathrm{CDCl}_{3}\right): \delta 17.6,18.2,18.5,19.0,21.5,25.4,25.7,26.6,26.7,34.7,37.7,38.0,114.7$, 124.5, 128.4, 129.0, 131.6, 134.0, 146.3, 154.1; HRMS $\left(\mathrm{ESI}^{+}\right)$for $\mathrm{C}_{20} \mathrm{H}_{29} \mathrm{NO}_{3} \mathrm{Na}[\mathrm{M}+\mathrm{Na}]^{+}$calcd. 354.2045 ; found 354.2042 .

Compound 3. IR: 2959, 2928, 2871, 1601, 1577, 1540, 1454, 1406, 1339, 1272, 1201, 1109, $1056 \mathrm{~cm}^{-1}$. ${ }^{1} \mathrm{H}-\mathrm{NMR}\left(\mathrm{CDCl}_{3}\right) \delta 0.99(3 \mathrm{H}, \mathrm{d}, J=6.8 \mathrm{~Hz}), 1.19(3 \mathrm{H}, \mathrm{d}, J=6.8 \mathrm{~Hz}), 1.3-1.1(2 \mathrm{H}, \mathrm{m}), 1.54(3 \mathrm{H}, \mathrm{s})$, $1.65(3 \mathrm{H}, \mathrm{s}), 2.0-1.6(7 \mathrm{H}, \mathrm{m}), 2.57(3 \mathrm{H}, \mathrm{s}), 3.24(1 \mathrm{H}, \mathrm{m}), 4.95(1 \mathrm{H}, \mathrm{t}, J=6.8 \mathrm{~Hz}), 6.63(1 \mathrm{H}, \mathrm{s}), 11.27$ $\left(1 \mathrm{H}\right.$, br s); ${ }^{13} \mathrm{C}-\mathrm{NMR}\left(\mathrm{CDCl}_{3}\right): \delta 17.7,18.8,18.8,22.9,22.9,25.8,26.2,26.9,27.0,33.4,37.9,42.9$, 124.5, 124.7, 131.5, 131.6, 132.2, 132.6, 140.9, 154.1; $\mathrm{HRMS}\left(\mathrm{ESI}^{+}\right)$for $\mathrm{C}_{20} \mathrm{H}_{29} \mathrm{NO}_{3} \mathrm{Na}[\mathrm{M}+\mathrm{Na}]^{+}$calcd. 354.2045 ; found 354.2033 .

\subsubsection{Preparation of 7-Bromo-14,15-dihydroleubethanol (4)}

A solution of leubethanol (306 mg, $1.1 \mathrm{mmol})$ in ethanol $(10 \mathrm{~mL})$ was treated with $\mathrm{H}_{2}$ under $10 \%$ Pd-C catalysis to provide 14,15-dihydroleubethanol in 95\% yield [12]. Then, 14,15-dihydroleubethanol (54 mg, $0.18 \mathrm{mmol})$ was dissolved in carbon tetrachloride $(3 \mathrm{~mL})$ and NBS (35 mg, $0.20 \mathrm{mmol})$ was added. The mixture was refluxed for $4 \mathrm{~h}$, followed to $1 \mathrm{~h}$ at $0{ }^{\circ} \mathrm{C}$. The solid residue was filtered off and the solvent was evaporated under reduced pressure to give a crude oil that was purified by silica flash chromatography using $n$-hexane/ethyl acetate (98:2) as eluent giving $44 \mathrm{mg}$ (67\%) of compound 4. IR: 3511, 2952, 2927, 2869, 1599, 1559, 1459, 1399, 1379, 1312, 1235, 1207, 1171, 1040, $980 \mathrm{~cm}^{-1}$. ${ }^{1} \mathrm{H}-\mathrm{NMR}\left(\mathrm{CDCl}_{3}\right): \delta 0.83(6 \mathrm{H}, \mathrm{d}, J=6.8 \mathrm{~Hz}), 0.94(3 \mathrm{H}, \mathrm{d}, J=6.8 \mathrm{~Hz}), 1.10-1.30(2 \mathrm{H}, \mathrm{m}), 1.19(3 \mathrm{H}, \mathrm{d}$, $J=7.2 \mathrm{~Hz}), 1.50-2.0(8 \mathrm{H}, \mathrm{m}), 2.34(3 \mathrm{H}, \mathrm{s}), 2.54(1 \mathrm{H}, \mathrm{m}), 3.18(1 \mathrm{H}, \mathrm{m}), 5.65(1 \mathrm{H}, \mathrm{br} \mathrm{s}), 6.66(1 \mathrm{H}, \mathrm{s})$; ${ }^{13} \mathrm{C}-\mathrm{NMR}\left(\mathrm{CDCl}_{3}\right): \delta(\mathrm{ppm}) 18.9,19.4,21.0,22.6,22.8,23.0,25.6,27.2,27.5,28.0,33.6,38.5,39.2$, $42.2,110.4,123.3,128.2,133.8,139.9,149.3$; $\mathrm{HRMS}\left(\mathrm{ESI}^{+}\right)$for $\mathrm{C}_{20} \mathrm{H}_{32} \mathrm{BrO}[\mathrm{M}+\mathrm{H}]^{+}$: calcd 367.1637; found 367.1646 . 


\subsubsection{Preparation of 14,15- $\alpha$-Epoxy-16-hydroxyleubethanol (7)}

L-(+)DET (60 $\mu \mathrm{L}, 0.34 \mathrm{mmol})$ was dissolved in $\mathrm{CH}_{2} \mathrm{Cl}_{2}(3.5 \mathrm{~mL})$ under nitrogen and the solution cooled to $-23{ }^{\circ} \mathrm{C}$, then $\mathrm{Ti}(i-\mathrm{PrO})_{4}(300 \mu \mathrm{L}, 6 \mathrm{M})$ was added and the mixture stirred for $15 \mathrm{~min}$. After that, a solution of compound $5(25 \mathrm{mg}, 0.08 \mathrm{mmol})$ in $\mathrm{CH}_{2} \mathrm{Cl}_{2}(1 \mathrm{~mL})$ [12], was added and the mixture stirred for $5 \mathrm{~min}$. Then, a solution of $3 \mathrm{M}$ of tert-butyl hydroperoxide (TBHP) in toluene $(0.2 \mathrm{~mL}, 0.6 \mathrm{mmol})$ was added and the mixture stirred for $12 \mathrm{~h}$. The reaction was quenched by the addition of a $10 \%$ aq. solution of tartaric acid $(1 \mathrm{~mL})$ and was stirred for $30 \mathrm{~min}$ at $-23{ }^{\circ} \mathrm{C}$, followed of $1 \mathrm{~h}$ at room temperature. The solution was filtered off through Celite, and the residue washed with diethyl ether. The organic layer was washed with water and reduced to a volume of $50 \mathrm{~mL}$, treated with $1 \mathrm{M}$ solution of $\mathrm{NaOH}(3 \mathrm{~mL})$ at $0{ }^{\circ} \mathrm{C}$ for $45 \mathrm{~min}$. The organic phase was washed with brine. The aqueous layer was extracted with $\mathrm{Et}_{2} \mathrm{O}$ and washed with brine. The combined organic layers were dried over sodium sulphate and concentrated to give an oil, which was purified by column chromatography with $n$-hexane/ethyl acetate (7:3) as eluent to give $13.6 \mathrm{mg}$ (65\%) of 14,15 - $\alpha$-epoxy-16-hydroxy-leubethanol (7) in $\approx 91 \%$ ee. IR: 3408, 2951, 2927, 2869, 1616, 1580, 1457, 1421, 1377, 1332, 1285, 1254, 1035, $842 \mathrm{~cm}^{-1}$; ${ }^{1} \mathrm{H}-\mathrm{NMR}$ $\left(\mathrm{CDCl}_{3}\right): \delta 0.98(3 \mathrm{H}, \mathrm{d}, J=6.8 \mathrm{~Hz}), 1.20(3 \mathrm{H}, \mathrm{d}, J=6.8 \mathrm{~Hz}), 1.21(3 \mathrm{H}, \mathrm{s}), 2.24(3 \mathrm{H}, \mathrm{s}), 2.60(1 \mathrm{H}, \mathrm{m})$, $2.93(1 \mathrm{H}, \mathrm{m}), 3.07(1 \mathrm{H}, \mathrm{m}), 3.63(2 \mathrm{H}, \mathrm{m}), 4.77(1 \mathrm{H}, \mathrm{br} \mathrm{s}), 6.43(1 \mathrm{H}, \mathrm{s}), 6.57(1 \mathrm{H}, \mathrm{s}) ;{ }^{13} \mathrm{C}-\mathrm{NMR}\left(\mathrm{CDCl}_{3}\right)$ : $\delta 14.2,18.8,21.1(2 \mathrm{C}), 26.6,26.6,27.4,30.0,38.5,39.2,42.3,60.4(2 \mathrm{C}), 65.3,114.4,122.2,126.3$, 135.3, 140.7, 153.1; HRMS (ESI) for $\mathrm{C}_{20} \mathrm{H}_{31} \mathrm{O}_{2}[\mathrm{M}+\mathrm{H}]^{+}$: calcd 303.2324; found 303.2369.

3.2.6. Preparation of $(E)-6 R-((1 S, 4 R)-5$-Hydroxy-4,7-dimethyl-1,2,3,4-tetrahydronaphthalen-1-yl)-2methylhept-2-enyl pyrazine-2-carboxylate (8)

A solution of pyrazinecarboxylic acid $(13.6 \mathrm{mg}, 0.11 \mathrm{mmol})$, allylic alcohol 5 (31.5 mg. $0.1 \mathrm{mmol})$, and $N, N$-dicyclohexylcarbodiimide $(22.7 \mathrm{mg}, 0.11 \mathrm{mmol})$ in $5 \mathrm{~mL}$ of dichloromethane was stirred for $24 \mathrm{~h}$ at room temperature. The mixture was filtered off and the filtrate washed with water, $5 \% \mathrm{HCl}$, and with water again, dried over sodium sulphate and the solvent removed under vacuum to give a crude oil that was purified by silica flash chromatography using $n$-hexane/ethyl acetate (9:1) as eluent to give $10 \mathrm{mg} \mathrm{(33 \% )} \mathrm{of} \mathrm{starting} \mathrm{material} \mathrm{and} 22 \mathrm{mg}(53 \%)$ of pyrazine ester derivative 8. IR: 3452, 2949, 2919, 1702, 1616, 1580, 1453, 1332, 1247, 1001, $890 \mathrm{~cm}^{-1}$; ${ }^{1} \mathrm{H}-\mathrm{NMR}\left(\mathrm{CDCl}_{3}\right) ; \delta 0.96(3 \mathrm{H}, \mathrm{d}, J=6.8 \mathrm{~Hz})$, 1.1-1.6 (6H, m), $1.18(3 \mathrm{H}, \mathrm{d}, J=7.2 \mathrm{~Hz}), 1.68(3 \mathrm{H}, \mathrm{s}), 1.9-2.1(6 \mathrm{H}, \mathrm{m}), 2.21(3 \mathrm{H}, \mathrm{s}), 2.56(1 \mathrm{H}, \mathrm{m}), 3.05$ $(1 \mathrm{H}, \mathrm{m}), 4.78(2 \mathrm{H}, \mathrm{s}), 5.47(1 \mathrm{H}, \mathrm{t}, J=7.2 \mathrm{~Hz}), 6.43(1 \mathrm{H}, \mathrm{s}), 6.55(1 \mathrm{H}, \mathrm{s}), 8.73(1 \mathrm{H}, \mathrm{dd}, J=1.6,2,4 \mathrm{~Hz})$; $8.75(1 \mathrm{H}, \mathrm{d}, J=2,4 \mathrm{~Hz}), 9.29(1 \mathrm{H}, \mathrm{d}, J=1.6 \mathrm{~Hz}) ;{ }^{13} \mathrm{C}-\mathrm{NMR}\left(\mathrm{CDCl}_{3}\right): \delta 14.1,18.7,19.3,21,1,21.1$, 26.2, 26.6, 27.4, 32.8, 38.2, 42.3, 72.2, 113.3, 122.3, 126.3.128.9, 131.8, 135.1, 140.7, 143.6, 144.5, 146.2, 147.5, 153.2, 163.8. HRMS $\left(\mathrm{ESI}^{+}\right)$for $\mathrm{C}_{25} \mathrm{H}_{32} \mathrm{~N}_{2} \mathrm{O}_{3} \mathrm{Na}[\mathrm{M}+\mathrm{Na}]^{+}$: calcd 431.2311; found 431.2304.

\subsubsection{Preparation of 16-Hydroximinoleubethanol (9)}

The 16-oxoleubethanol 6 (43 $\mathrm{mg}, 0.14 \mathrm{mmol})$ dissolved in methanol $(5 \mathrm{~mL})$ was treated with hydroxylamine hydrochloride $(97 \mathrm{mg}, 1.4 \mathrm{mmol}$ ) and 5 drops of pyridine and the mixture was refluxed for $14 \mathrm{~h}$. The solvent was removed under vacuum and the crude dissolved in dichloromethane, the organic layer was washed with water and dried over $\mathrm{Na}_{2} \mathrm{SO}_{4}$. Removal of the solvent gave $40 \mathrm{mg}$ of a crude, that was purified by silica flash chromatography using $n$-hexane/ethyl acetate $(9: 1)$ as eluent, to 
provide $20 \mathrm{mg}$ (50\%) of 9. IR: 3367, 2922, 2862, 1616, 1580, 1454, 1372, 1321, 1285, 1253, 1171, 1054, $995 \mathrm{~cm}^{-1}$; ${ }^{1} \mathrm{H}-\mathrm{NMR}\left(\mathrm{CDCl}_{3}\right): \delta 0.99(3 \mathrm{H}, \mathrm{d}, J=6.8 \mathrm{~Hz}), 1.3-1.6(4 \mathrm{H}, \mathrm{m}), 1.20(3 \mathrm{H}, \mathrm{d}, J=6.8 \mathrm{~Hz}), 1.77$ $(3 \mathrm{H}, \mathrm{s}), 1.8-2.2(6 \mathrm{H}, \mathrm{m}), 2.24(3 \mathrm{H}, \mathrm{s}), 2.60(1 \mathrm{H}, \mathrm{m}), 3.06(1 \mathrm{H}, \mathrm{m}), 5.59(1 \mathrm{H}, \mathrm{t}, J=7.6 \mathrm{~Hz}), 6.43(1 \mathrm{H}, \mathrm{s}), 6.56$ $(1 \mathrm{H}, \mathrm{s}), 7.66(1 \mathrm{H}, \mathrm{s}), 8.10(1 \mathrm{H}, \mathrm{br} \mathrm{s}) ;{ }^{13} \mathrm{C}-\mathrm{NMR}\left(\mathrm{CDCl}_{3}\right): \delta 11.9,18.6,19.2,21.0,21.4,26.5,26.5,27.5$, $32.5,38.2,42.2,113.3,122.3,126.2,130.2,135.2,139.9,140.6,153.0,154.9$; HRMS (ESI+) for $\mathrm{C}_{20} \mathrm{H}_{30} \mathrm{NO}_{2}[\mathrm{M}+\mathrm{H}]^{+}$calcd. 316. 2277; found 316.2271.

3.2.8. Preparation of 2-((E)-6R-((1S,4R)-5-Hydroxy-4,7-dimethyl-1,2,3,4-tetrahydronaphthalen-1yl)hept-2-en-2-yl)-2H-pyran-4(3H)-one (10)

To a solution of trans-methoxytrimethylsilyloxy-1,3-butadiene (40 $\mathrm{mg}, 0.23 \mathrm{mmol}$ ) in dry diethyl ether $(5 \mathrm{~mL})$ under nitrogen atmosphere at $-30{ }^{\circ} \mathrm{C}$ aldehyde $6(75 \mathrm{mg}, 0.23 \mathrm{mmol})$ dissolved in diethyl ether $(2 \mathrm{~mL})$ and boron trifluoride diethyl etherate $(45 \mu \mathrm{L}, 0.23 \mathrm{mmol})$ were added. The mixture was maintained for 4 hours under stirring and the reaction was quenched by the addition of $\mathrm{Et}_{3} \mathrm{~N}$ (96 $\mu \mathrm{L}$, $0.69 \mathrm{mmol})$ and water $(2 \mathrm{~mL})$. The mixture was treated with diethyl ether, washed with brine and the organic layer dried with $\mathrm{Na}_{2} \mathrm{SO}_{4}$. The crude was dissolved in dichloromethane $(5 \mathrm{~mL})$ and 4 drops of trifluoroacetic acid was added. One hour later, the solvent was evaporated under reduced pressure to give a crude that was purified by silica flash chromatography using $n$-hexane/ethyl acetate (9:1) as eluent giving $20 \mathrm{mg}$ (26\%) of starting material and $38 \mathrm{mg}$ (48\%) of dihydropyranone derivative 10. IR: 3402, 2953, 2923, 2869, 1661, 1588, 1502, 1454, 1413, 1278, 1226, 1174, 1050, $984 \mathrm{~cm}^{-1}$; ${ }^{1} \mathrm{H}-\mathrm{NMR}\left(\mathrm{CDCl}_{3}\right)$ : $\delta 0.99(3 \mathrm{H}, \mathrm{d}, J=6.8 \mathrm{~Hz}), 1.19(3 \mathrm{H}, \mathrm{d}, J=6.9 \mathrm{~Hz}), 2.23(3 \mathrm{H}, \mathrm{s}), 2.35(3 \mathrm{H}, \mathrm{s}), 2.59(1 \mathrm{H}, \mathrm{m}), 2.73(1 \mathrm{H}$, $\mathrm{dd}, J=16.7,14.5 \mathrm{~Hz}), 3.08(1 \mathrm{H}, \mathrm{m}) .4 .69(1 \mathrm{H}, \mathrm{dd}, J=14.5,2.4 \mathrm{~Hz}), 5.42(2 \mathrm{H}, \mathrm{m}), 6.44(1 \mathrm{H}, \mathrm{s}), 6.56$ $(1 \mathrm{H}, \mathrm{s}), 7.39(1 \mathrm{H}, \mathrm{dt}, J=6.1,1.0 \mathrm{~Hz}) ;{ }^{13} \mathrm{C}-\mathrm{NMR}\left(\mathrm{CDCl}_{3}\right): \delta 11.9,18.7,19.2,21.1,21.1,26.0,26.5,27.5$, $32.7,38.2,40.6,42.2,84.5,106.7,113.3,122.2,126.3,130.8,131.2,135.0,140.6,153.2,163.6,193.2$; HRMS (ESI ${ }^{+}$) for $\mathrm{C}_{24} \mathrm{H}_{32} \mathrm{O}_{3} \mathrm{Na}[\mathrm{M}+\mathrm{Na}]^{+}$calcd. 391.2249; found 391.2239.

3.2.9. Preparation of $(5 S, 8 R)-5-((2 R)-4-(1,4-D i m e t h y l-1 H$-pyrazol-3-yl)butan-2-yl)-3,8-dimethyl5,6,7,8-tetrahydronaphthalen-1-ol (11)

To a stirring solution of 16-oxoleubethanol 6 (19 $\mathrm{mg}, 0.06 \mathrm{mmol})$ in 2-propanol $(2 \mathrm{~mL})$, methylhydrazine ( $26 \mu \mathrm{L}, 0.5 \mathrm{mmol})$ was added and the mixture refluxed for 5 hours. The solvent was removed under reduced pressure to give a crude oil that was purified by silica flash chromatography using $n$-hexane/ethyl acetate $(9: 1)$ as eluent to give $11 \mathrm{mg}(55 \%)$ of the pyrazole 11. IR: 3209, 2929, 2864, 1613, 1578, 1451, 1419, 1371, 1321, 1285, 1260, 1172, $1059 \mathrm{~cm}^{-1} .{ }^{1} \mathrm{H}-\mathrm{NMR}\left(\mathrm{CDCl}_{3}\right): \delta 1.02(3 \mathrm{H}$, $\mathrm{d}, J=6.8 \mathrm{~Hz}), 1.10-1.30(2 \mathrm{H}, \mathrm{m}), 1.18(3 \mathrm{H}, \mathrm{d}, J=7.2 \mathrm{~Hz}), 1.50-203(8 \mathrm{H}, \mathrm{m}), 1.85(3 \mathrm{H}, \mathrm{s}), 2.20(3 \mathrm{H}$, s), $2.59(1 \mathrm{H}, \mathrm{m}), 3.02(1 \mathrm{H}, \mathrm{m}), 3.75(3 \mathrm{H}, \mathrm{s}), 5.31(1 \mathrm{H}$, br s), $6.40(1 \mathrm{H}, \mathrm{s}), 6.50(1 \mathrm{H}, \mathrm{br} \mathrm{s}), 7.00(1 \mathrm{H}, \mathrm{br}$ $\mathrm{s}) ;{ }^{13} \mathrm{C}-\mathrm{NMR}\left(\mathrm{CDCl}_{3}\right): \delta 8.2,18.7,19.6,21.1,21.2,25.0,26.7,27.5,33.0,38.2,38.3,42.4,113.2,113.5$, 122.2, 126.3, 129.5, 135.0, 140.8, 151.5, 153.3; HRMS (ESI+) for $\mathrm{C}_{21} \mathrm{H}_{31} \mathrm{~N}_{2} \mathrm{O}[\mathrm{M}+\mathrm{H}]^{+}$: calcd 327.2436; found 367.2439 . 
3.2.10. Preparation of $\left(5 S, 5^{\prime} S, 8 R, 8^{\prime} R\right)-5,5^{\prime}-\left(\left(2 R, 2^{\prime} R, 5 E, 5^{\prime} E, 7 Z, 7^{\prime} Z\right)-7,7^{\prime}-(E t h a n e-1,2-d i y l b i s(a z a n-1-y l-\right.$ 1-ylidene))bis(6-methylhept-5-ene-2-yl-7-ylidene))bis(3,8-dimethyl-5,6,7,8-tetrahydronaphthalen-1ol) (12a)

To a solution of compound $6(91 \mathrm{mg}, 0.3 \mathrm{mmol})$ in dry toluene $(1.5 \mathrm{~mL})$, ethyendiamine $(10 \mathrm{~mL}$, $0.15 \mathrm{mmol})$ and anhydrous $\mathrm{Na}_{2} \mathrm{SO}_{4}(900 \mathrm{mg})$ were added. The mixture was maintained at room temperature for $19 \mathrm{~h}$. The solid was filtered, and the solvent was removed under reduced pressured to isolated $92 \mathrm{mg}$ (95\%) of the diimine derivative 12a. IR: 3447, 2925, 1654, 1624, 1458, $1119 \mathrm{~cm}^{-1}$. ${ }^{1} \mathrm{H}-\mathrm{NMR}\left(\mathrm{CDCl}_{3}\right): \delta 0.96(3 \mathrm{H}, \mathrm{d}, J=7.6 \mathrm{~Hz}), 1.18(3 \mathrm{H}, \mathrm{d}, J=6.8 \mathrm{~Hz}), 1.20-1.60(4 \mathrm{H}, \mathrm{m}), 1.76(3 \mathrm{H}, \mathrm{s})$, 1.8-2.10 (6H, m), $2.19(3 \mathrm{H}, \mathrm{s}), 2.56(1 \mathrm{H}, \mathrm{m}), 3.07(1 \mathrm{H}, \mathrm{m}), 3.70(2 \mathrm{H}, \mathrm{s}), 5.69(1 \mathrm{H}, \mathrm{t}, J=6.8 \mathrm{~Hz}), 6.38$ $(1 \mathrm{H}, \mathrm{s}), 6.51(1 \mathrm{H}, \mathrm{s}), 7.69(1 \mathrm{H}, \mathrm{s}) ;{ }^{13} \mathrm{C}-\mathrm{NMR}\left(\mathrm{CDCl}_{3}\right) \delta 12.4,19.6,20.0(2 \mathrm{C}), 22.0,27.5,27.7,28.4$, $33.3,39.2,43.1,62.1,114.1,122.7,127.5,135.9,136.3,141.5,144.1,154.5,168.7 . \mathrm{HRMS}_{(\mathrm{ESI}}^{+}$) for $\mathrm{C}_{42} \mathrm{H}_{61} \mathrm{~N}_{2} \mathrm{O}_{2}[\mathrm{M}+\mathrm{H}]^{+}$calcd. 625.4732; found 625.4728.

3.2.11. Preparation of $\left(5 S, 5^{\prime} S, 8 R, 8^{\prime} R\right)-5,5^{\prime}-\left(\left(2 R, 2^{\prime} R, 5 E, 5^{\prime} E\right)-7,7^{\prime}\right.$-(Ethane-1,2-diylbis(azanediyl))-bis(6methylhept-5-ene-7,2-diyl))bis(3,8-dimethyl-5,6,7,8-tetrahydronaphthalen-1-ol) (12b)

Diimine 12a ( $83 \mathrm{mg}, 0.13 \mathrm{mmol})$ was dissolved in ethanol $(2 \mathrm{~mL})$, and a solution of $\mathrm{NaBH}_{4}(10 \mathrm{mg}$, $0.26 \mathrm{mmol})$ in anhydrous ethanol $(1 \mathrm{~mL})$ was added. The mixture was maintained for $3 \mathrm{~h}$ at $40{ }^{\circ} \mathrm{C}$, cooled, diluted with water $(5 \mathrm{~mL})$, treated with a $5 \% \mathrm{NaOH}$, and extracted with dichloromethane. The organic layer was washed with brine, dried over $\mathrm{K}_{2} \mathrm{CO}_{3}$, and the solvent was removed under reduced pressure to isolated $79 \mathrm{mg}(90 \%)$ of ethylendiamine derivative 12b. IR: 3450, 2925, 1654, 1617, 1578, 1458, $840 \mathrm{~cm}^{-1} .{ }^{1} \mathrm{H}-\mathrm{NMR}\left(\mathrm{CDCl}_{3}\right): \delta 0.89(3 \mathrm{H}, \mathrm{d}, J=6.8 \mathrm{~Hz}), 1.00-1.25(4 \mathrm{H}, \mathrm{m}), 1.11(3 \mathrm{H}, \mathrm{d}, J=6.0 \mathrm{~Hz})$, 1.50-2.0 (8H, m), $1.75(3 \mathrm{H}, \mathrm{s}), 2.15(3 \mathrm{H}, \mathrm{s}), 2.50(1 \mathrm{H}, \mathrm{m}), 2.52(1 \mathrm{H}, \mathrm{m}), 3.01(2 \mathrm{H}, \mathrm{m}), 5.09(1 \mathrm{H}$, br. s), $6.33(1 \mathrm{H}, \mathrm{s}), 6.48(1 \mathrm{H}, \mathrm{s}) ;{ }^{13} \mathrm{C}-\mathrm{NMR}\left(\mathrm{CDCl}_{3}\right): \delta 14.7,18.8,19.4,21.2(2 \mathrm{C}), 26.1,26.6,26.5,33.2,38.2$, $42.4,47.7,57.3,113.3,121.7,126.8,127.5,132.4,134.8,140.7,153.9$; HRMS (ESI ${ }^{+}$) for $\mathrm{C}_{42} \mathrm{H}_{65} \mathrm{~N}_{2} \mathrm{O}_{2}$ $[\mathrm{M}+\mathrm{H}]^{+}$calcd. 629.5042 ; found 629.5038 .

3.2.12. Preparation of $(R, E)-6-((1 S, 4 R)-4,7-D i m e t h y 1-5,8$-dioxo-1,2,3,4,5,8-hexahydronaphthalen-1yl)-2-methylhept-2-enoic acid (13)

The aldehyde 6 (60 mg, $0.17 \mathrm{mmol}$ ) was dissolved in tert-butyl alcohol (4 mL) and 2-methyl-2-butene $(1 \mathrm{~mL})$. Then, a solution of sodium chlorite $(141 \mathrm{mg}, 1.56 \mathrm{mmol})$ and sodium hydrogen phosphate $(126 \mathrm{mg}, 1.05 \mathrm{mmol})$ in water $(2 \mathrm{~mL})$ was added dropwise over a 10 minute period. The reaction mixture was stirred at room temperature overnight. The solvent was removed under reduced pressured, and the residue dissolved in water $(10 \mathrm{~mL})$ and extracted with hexane $(2 \times 8 \mathrm{~mL})$. The combined organic layers were dried with $\mathrm{Na}_{2} \mathrm{SO}_{4}$, filtered and evaporated under reduced pressure to give $40 \mathrm{mg}(72 \%)$ of the quinone 13. IR: 3520, 2930, 2870, 1710, 1690, 1660, 1606, 1516, 1453, 1281, 1128, $890 \mathrm{~cm}^{-1}$; ${ }^{1} \mathrm{H}-\mathrm{NMR}$ $\left(\mathrm{CDCl}_{3}\right): \delta 0.85(3 \mathrm{H}, \mathrm{d}, J=6.8 \mathrm{~Hz}), 1.06(3 \mathrm{H}, \mathrm{d}, J=6.8 \mathrm{~Hz}), 1.10-1.30(2 \mathrm{H}, \mathrm{m}), 1.79(3 \mathrm{H}, \mathrm{s}), 1.60-2.20$ $(7 \mathrm{H}, \mathrm{m}), 2.00(3 \mathrm{H}, \mathrm{s}), 2.78(1 \mathrm{H}, \mathrm{m}), 2.93(1 \mathrm{H}, \mathrm{m}), 6.52(1 \mathrm{H}, \mathrm{s}), 6.80(1 \mathrm{H}, \mathrm{t}, J=6.8 \mathrm{~Hz}), 8.20(1 \mathrm{H}$, br s$)$; ${ }^{13} \mathrm{C}-\mathrm{NMR}\left(\mathrm{CDCl}_{3}\right): \delta 11.9,15.8,18.5,19.3,21.0,25.2,26.6,26.8,33.4,35.8,36.7,127.1,133.4,144.9$, 145.0, 145.4, 147.4, 173.2, 187.1, 188.4; HRMS (ESI+) for $\mathrm{C}_{20} \mathrm{H}_{26} \mathrm{O}_{4} \mathrm{Na}[\mathrm{M}+\mathrm{Na}]^{+}$calcd. 353.1729; found 353.1714 . 
3.2.13. Preparation of $(5 R, 8 S)$-2,5-Dimethyl-8-((E,R)-6-methylhept-5-en-2-yl)-5,6,7,8tetrahydronaphthalene-1,4-dione (14)

Leubethanol (74 mg, $0.26 \mathrm{mmol})$ was dissolved in in tert-butyl alcohol $(9 \mathrm{~mL})$ and 2-methyl-2-butene ( $2 \mathrm{~mL}$ ). Then, a solution of sodium chlorite $(216 \mathrm{mg}, 3.4 \mathrm{mmol})$ and sodium hydrogen phosphate $(210 \mathrm{mg}, 1.8 \mathrm{mmol})$ in water $(2 \mathrm{~mL})$ was added dropwise over a 10 minute period. The reaction mixture was stirred at room temperature overnight. The solvent was removed under reduced pressured, the residue dissolved in $10 \mathrm{~mL}$ of water and extracted with hexane $(2 \times 10 \mathrm{~mL})$. The combined organic layers were dried with $\mathrm{Na}_{2} \mathrm{SO}_{4}$, filtered and evaporated under reduced pressure to give $30 \mathrm{mg}$ of starting material and $35 \mathrm{mg}$ (48\%) of the quinone 14. IR: 2957, 2926, 1718, 1676, 1601, 1540, 1410, 1272, 1201, 1109, $890 \mathrm{~cm}^{-1} ;{ }^{1} \mathrm{H}-\mathrm{NMR}\left(\mathrm{CDCl}_{3}\right): \delta 0.78(3 \mathrm{H}, \mathrm{d}, J=6.8 \mathrm{~Hz}), 1.01(3 \mathrm{H}, \mathrm{d}, J=6.8 \mathrm{~Hz})$, 1.10-1.40 (2H, m), $1.49(3 \mathrm{H}, \mathrm{s}), 1.58(3 \mathrm{H}, \mathrm{s}), 1.60-2.20(7 \mathrm{H}, \mathrm{m}), 1.95(3 \mathrm{H}, \mathrm{s}), 2.70(1 \mathrm{H}, \mathrm{m}), 2.87(1 \mathrm{H}$, $\mathrm{m}), 4.93(1 \mathrm{H}, \mathrm{t}, J=7.2 \mathrm{~Hz}) ; 6.44(1 \mathrm{H}, \mathrm{s}) ;{ }^{13} \mathrm{C}-\mathrm{NMR}\left(\mathrm{CDCl}_{3}\right): \delta 15.7,17.6,18.7,19.0,21.1,25.6,25.7$, 26.3, 26.5, 34.8, 36.6, 37.6, 124.1, 131.5, 133.4, 143.2, 145.5, 147.0, 187.3, 188.4; HRMS (ESI+) for $\mathrm{C}_{20} \mathrm{H}_{29} \mathrm{O}_{2}[\mathrm{M}+\mathrm{H}]^{+}$calcd. 301.2168; found 301.2164.

\subsubsection{Preparation of 8-Acetoxyleubethanol (15)}

Distilled $\mathrm{Ac}_{2} \mathrm{O}(0.5 \mathrm{~mL})$ was added to a solution of leubethanol $(97 \mathrm{mg}, 0.33 \mathrm{mmol})$ in pyridine $(2 \mathrm{~mL})$. After 12 hours the reaction was quenched with ice, one hour later the mixture was extracted with EtOAc and the organic layer was washing with $10 \% \mathrm{HCl}, 5 \% \mathrm{NaHCO}_{3}$, brine and finally dried over $\mathrm{Na}_{2} \mathrm{SO}_{4}$. The solvent was evaporated under reduced pressure to give a crude oil that was purified by chromatography on silica gel $n$-hexane/EtOAc (95:5) to give $104 \mathrm{mg}$ of acetylated Leub, compound 15 (95\%). IR: 2954, 2926, 2870, 1765, 1619, 1571, 1451, 1370, 1207, $1048 \mathrm{~cm}^{-1} .{ }^{1} \mathrm{H}-\mathrm{NMR}\left(\mathrm{CDCl}_{3}\right): \delta 0.99$ $(3 \mathrm{H}, \mathrm{d}, J=7.1 \mathrm{~Hz}, 3 \mathrm{H}), 1.15(3 \mathrm{H}, \mathrm{d}, J=6.8 \mathrm{~Hz}), 1.59(3 \mathrm{H}, \mathrm{s}), 1.68(3 \mathrm{H}, \mathrm{s}), 2.31(6 \mathrm{H}, \mathrm{s}), 2.61(1 \mathrm{H}, \mathrm{m})$, $2.95(1 \mathrm{H}, \mathrm{m}), 5.01(1 \mathrm{H}, \mathrm{t}, J=7.1 \mathrm{~Hz}), 6.70(1 \mathrm{H}, \mathrm{s}), 6.88(1 \mathrm{H}, \mathrm{s}) ;{ }^{13} \mathrm{C}-\mathrm{NMR}\left(\mathrm{CDCl}_{3}\right): \delta 17.7,18.8,19.3$, 21.2 (2C), 21.8, 25.8, 26.3, 27.2, 27.4, 33.2, 38.0, 42.3, 120.3, 124.9, 127.6, 131.2, 131.6, 135.1, 141.2, 148.7, 169.7; HRMS $\left(\mathrm{ESI}^{+}\right)$for $\mathrm{C}_{22} \mathrm{H}_{33} \mathrm{O}_{2}[\mathrm{M}+\mathrm{H}]^{+}$: calcd. 329.2481; found 329.2502.

\subsubsection{Preparation of $(5 S, 8 R)-5-((E, R)-6$-Hydroxy-6-methylhept-4-en-2-yl)-3,8-dimethyl-5,6,7,8-} tetrahydronaphthalen-1-yl acetate (16)

To a magnetic stirred, ice-cooled solution of diphenyldiselenide (590 mg, $1.89 \mathrm{mmol}$ ) in dry dichloromethane $(7 \mathrm{~mL})$ was slowly added chilled $33 \%$ of hydrogen peroxide $(0.21 \mathrm{~mL}, 64.2 \mathrm{mg}$, $1.89 \mathrm{mmol}$ ). After stirring vigorously for $30 \mathrm{~min}$ (white crystals deposit within $10 \mathrm{~min}$ ), powered anhydrous magnesium sulfate $(300 \mathrm{mg}$ ) was added and the mixture was stirred for an additional $30 \mathrm{~min}$ in the ice-bath. The ice bath was removed, compound 15 (408 $\mathrm{mg}, 0.86 \mathrm{mmol})$ was added and the mixture stirred vigorously for $6 \mathrm{~h}$ at $25{ }^{\circ} \mathrm{C}$. Chilled 3M tert-butyl hydroperoxide $(1.4 \mathrm{~mL}, 4.3 \mathrm{mmol})$ was added to the reaction mixture which had been immersed in an ice bath; then, after removing the ice bath, the mixture was stirred for $20 \mathrm{~h}$ at $25^{\circ} \mathrm{C}$ to give a pale orange solution with a lot of white precipitated. The white precipitate $\left(\mathrm{PhSeO}_{2} \mathrm{H}\right.$ and hydrated $\left.\mathrm{MgSO}_{4}\right)$, was filter off and washed with ethyl acetate. The filtrate was concentrated to give an oil. The oil was dissolved in ethyl acetate $(100 \mathrm{~mL})$ and washed with $5 \% \mathrm{Na}_{2} \mathrm{CO}_{3}$ water, $10 \% \mathrm{FeSO}_{4}$, water, (sat) $\mathrm{NaHCO}_{3}$, water and brine, successively and then, it was dried 
over $\mathrm{Na}_{2} \mathrm{SO}_{4}$. The solvent was evaporated under reduced pressure to give a crude oil that was purified by chromatography on silica gel $n$-hexane/ethyl acetate (98:2) to give $152 \mathrm{mg}$ of starting material and $245 \mathrm{mg}$ (56\%) of allyl alcohol 16. IR: 3454, 2950, 2922, 2872, 1763, 1618, 1571, 1453, 1370, 1207, 1140, 971, $881 \mathrm{~cm}^{-1} .{ }^{1} \mathrm{H}-\mathrm{NMR}\left(\mathrm{CDCl}_{3}\right): \delta 0.95(3 \mathrm{H}, \mathrm{d}, J=6.8 \mathrm{~Hz}), 1.12(3 \mathrm{H}, \mathrm{d}, J=6.8 \mathrm{~Hz}), 1.22(3 \mathrm{H}$, s), $1.23(3 \mathrm{H}, \mathrm{s}), 2.28(3 \mathrm{H}, \mathrm{s}), 2.29(3 \mathrm{H}, \mathrm{s}), 2.62(1 \mathrm{H}, \mathrm{m}), 2.91(1 \mathrm{H}, \mathrm{m}), 5.3-5.6(2 \mathrm{H}, \mathrm{m}), 6.67(1 \mathrm{H}, \mathrm{s})$, $6.87(1 \mathrm{H}, \mathrm{s}) ;{ }^{13} \mathrm{C}-\mathrm{NMR}\left(\mathrm{CDCl}_{3}\right): \delta 18.8,19.3,21.1,21.1,21.6,27.2,27.2,29.7,29.8,36.3,39.3,41.6$, 70.6, 120.4, 126.3, 127.8, 131.6, 135.3, 139.0, 141.1, 148.7, 169.8; HRMS (ESI ${ }^{+}$) for $\mathrm{C}_{22} \mathrm{H}_{32} \mathrm{O}_{3} \mathrm{Na}$ $[\mathrm{M}+\mathrm{Na}]^{+}$: calcd. 367.2249; found 367.2295.

3.2.16. Preparation of $(3 R, 7 S, 9 R, 9 \mathrm{a} S)-3,6,9$-Trimethyl-7-(2-methylprop-1-enyl)-2,3,7,8,9,9ahexahydro-1H-phenalen-4-yl acetate (17a) and (3R,7R,9S,9aS)-3,6,9-Trimethyl-7-(2-methylprop-1enyl)-2,3,7,8,9,9a-hexahydro-1H-phenalen-4-yl acetate (17b)

A solution of allylic alcohol $16(70 \mathrm{mg}, 0.20 \mathrm{mmol})$ was cooled to $-78{ }^{\circ} \mathrm{C}$ and treated dropwise with methanesulfonic acid $(65 \mu \mathrm{L}, 1.0 \mathrm{mmol})$. The solution was warmed to $-40{ }^{\circ} \mathrm{C}$ and stirred for $12 \mathrm{~h}$, and then triethylamine $(0.50 \mathrm{~mL})$ was added. The mixture was warmed to $20^{\circ} \mathrm{C}$, filtered off through a small plug of silica gel with hexane, and concentrate in vacuo to afford $63 \mathrm{mg}$ (97\%) of a mixture of compounds $\mathbf{1 7} \mathbf{a}+\mathbf{1 7} \mathbf{b}(2: 1)$.

Compound 17a. IR: 2925, 2863, 1762, 1598, 1452, 1370, 1209, $1036 \mathrm{~cm}^{-1} .{ }^{1} \mathrm{H}-\mathrm{NMR}\left(\mathrm{CDCl}_{3}\right): \delta 0.86$ $(3 \mathrm{H}, \mathrm{d}, J=7.1 \mathrm{~Hz}), 1.19(3 \mathrm{H}, \mathrm{d}, J=6.9 \mathrm{~Hz}), 1.67(3 \mathrm{H}, \mathrm{s}), 1.72(3 \mathrm{H}, \mathrm{s}), 2.12(3 \mathrm{H}, \mathrm{s}), 2.29(3 \mathrm{H}, \mathrm{s}), 2.70$ $(1 \mathrm{H}, \mathrm{m}), 3.02(1 \mathrm{H}, \mathrm{m}), 3.65(1 \mathrm{H}, \mathrm{m}), 5.16(1 \mathrm{H}, \mathrm{m}), 6.68(1 \mathrm{H}, \mathrm{s}) ;{ }^{13} \mathrm{C}-\mathrm{NMR}\left(\mathrm{CDCl}_{3}\right): \delta 16.0,17.6,19.9$, 21.1, 22.7, 25.3, 27.1, 28.6, 30.8, 31.5, 34.7, 37.3, 39.9, 121.7, 128.8, 131.4, 132.6, 135.0, 135.5, 137.2, 146.9, 169.7; HRMS (ESI ${ }^{+}$) for $\mathrm{C}_{22} \mathrm{H}_{30} \mathrm{O}_{2} \mathrm{Na}[\mathrm{M}+\mathrm{Na}]^{+}$: calcd. 349.2143; found 349.2154.

Compound 17b. IR: 2925, 2863, 1762, 1598, 1452, 1370, 1209, $1036 \mathrm{~cm}^{-1} .{ }^{1} \mathrm{H}-\mathrm{NMR}\left(\mathrm{CDCl}_{3}\right) \delta 0.72$ $(3 \mathrm{H}, \mathrm{d}, J=7.1 \mathrm{~Hz}), 1.20(3 \mathrm{H}, \mathrm{d}, J=6.9 \mathrm{~Hz}), 1.68(3 \mathrm{H}, \mathrm{s}), 1.72(3 \mathrm{H}, \mathrm{s}), 2.13(3 \mathrm{H}, \mathrm{s}), 2.29(3 \mathrm{H}, \mathrm{s}), 2.70$ $(1 \mathrm{H}, \mathrm{m}), 3.02(1 \mathrm{H}, \mathrm{m}), 3.63(1 \mathrm{H}, \mathrm{m}), 3.82(1 \mathrm{H}, \mathrm{ddd}, J=8.7,8.7,8.7 \mathrm{~Hz}) ; 5.01(1 \mathrm{H}$, br d, $J=8.7 \mathrm{~Hz}$ ), $6.66\left(1 \mathrm{H}\right.$, br s); ${ }^{13} \mathrm{C}-\mathrm{NMR}\left(\mathrm{CDCl}_{3}\right): \delta 13.6,17.4,20.0,21.1,23.0,25.4,27.2,28.7,31.2$, $31.4,33.6,37.5,40.3,121.6,129.0,129.8,131.3,135.1,135.2,138.1,149.6,169.7$.

\subsubsection{Preparation of (3R,7S,9R,9a $S)-3,6,9$-Trimethyl-7-(2-methylprop-1-enyl)-2,3,7,8,9,9a-} hexahydro-1H-phenalen-4-ol (18)

Acetyl compound 17a (53 mg, $0.16 \mathrm{mmol}$ ) was dissolved in $\mathrm{KOH} / \mathrm{MeOH}(5 \mathrm{~mL}, 2 \mathrm{M})$ and stirred for $12 \mathrm{~h}$. After that time, the solvent was evaporated, the residue was dissolved in water and extracted with ethyl acetate. The organic layer was dried over $\mathrm{Na}_{2} \mathrm{SO}_{4}$, and the solvent was evaporated under reduced pressure to give a crude oil that was purified by chromatography on silica gel $n$-hexane/ ethyl acetate (98:2) to give $35 \mathrm{mg} \mathrm{63 \% )} \mathrm{of} \mathrm{alcohol} \mathrm{compound} \mathrm{18.} \mathrm{IR:} \mathrm{3516,} \mathrm{2958,} \mathrm{2921,} \mathrm{2866,} \mathrm{1589,} \mathrm{1450,} \mathrm{1412,}$ 1377, 1237, 1177, 1031, 908, $732 \mathrm{~cm}^{-1} .{ }^{1} \mathrm{H}-\mathrm{NMR}\left(\mathrm{CDCl}_{3}\right): \delta 0.70(3 \mathrm{H}, \mathrm{d}, J=7.0 \mathrm{~Hz}) ; 1.28(3 \mathrm{H}, \mathrm{d}$, $J=6.8 \mathrm{~Hz}) ; 1.67(3 \mathrm{H}, \mathrm{s}) ; 1.71(3 \mathrm{H}, \mathrm{s}) ; 2.10(3 \mathrm{H}, \mathrm{s}) ; 2.68(1 \mathrm{H}, \mathrm{m}) ; 3.11(1 \mathrm{H}, \mathrm{m}) ; 3.61(1 \mathrm{H}, \mathrm{q}$, $J=9.0 \mathrm{~Hz}) ; 4.98(1 \mathrm{H}, \mathrm{dt}, J=9.3,1.3 \mathrm{~Hz}) ; 6.42(1 \mathrm{H}, \mathrm{s}) ;{ }^{13} \mathrm{C}-\mathrm{NMR}\left(\mathrm{CDCl}_{3}\right): \delta 13.3,17.4,19.9,22.8$, 
27.8, 28.5, 29.4, 31.4, 32.0, 33.2, 37.7, 40.8, 115.4, 125.7, 128.4, 129.6, 130.6, 135.1, 138.8, 151.4. HRMS $\left(\mathrm{ESI}^{+}\right.$) for $\mathrm{C}_{20} \mathrm{H}_{29} \mathrm{O}[\mathrm{M}+\mathrm{H}]^{+}$: calcd. 385.2218; found 385.2255.

\subsection{In Vitro Antimycobacterial Evaluation}

The antimycobacterial activity was assessed against M. tuberculosis H37Rv ATTC 27294 susceptible to all five first-line anti-TB drugs (streptomycin, isoniazid, rifampin, ethambutol, and pyrazinamide) in a modified Microplate Assay Blue Alamar [22,23]. The compounds for M. tuberculosis bioassays were prepared at a concentration of $1 \mathrm{mg} / \mathrm{mL}$ in $2.5 \%$ DMSO in Middlebrook $7 \mathrm{H} 9$ (Becton Dickinson and Co., Sparks, MD, USA) broth. All solutions were sterilized by filtration using $13 \mathrm{~mm}$ diameter PTFE acro-discs (0.22 $\mu \mathrm{m}$ pore size, Millipore Co., Bedford, MA, USA). The concentrations for organic compounds used ranged from $100 \mu \mathrm{g} / \mathrm{mL}$ to $0.78 \mu \mathrm{g} / \mathrm{mL}$, results are reported as minimal inhibition concentration (MIC). Ethambutol (EMB) was used as positive control. All biological assays were developed at least by triplicate.

\subsection{Cytotoxicity Assay}

Cytotoxicity was determined according to the MTT method [24] using African green monkey kidney epithelial cells (Vero cells) grown in RPMI-1640 medium supplemented with penicillin (100 units/mL), streptomycin $(100 \mu \mathrm{g} / \mathrm{mL})$, and fetal bovine serum $(10 \%)$ at $37{ }^{\circ} \mathrm{C}$ under $5 \% \mathrm{CO}_{2}$. In the confluence, 4000 cells per well was applied to a 96 -well microtitre plate. After incubation for $24 \mathrm{~h}\left(37{ }^{\circ} \mathrm{C}, 5 \% \mathrm{CO}_{2}\right)$, $10 \mu \mathrm{L}$ of a solution containing concentrations ranging from 500 to $0.5 \mu \mathrm{g} / \mathrm{mL}$ of the compound under evaluation was added and incubated for 48 h. $25 \mu \mathrm{L}$ of MTT ( $4 \mathrm{mg} / \mathrm{mL}$ in PBS) was added to each well and incubated for another $3 \mathrm{~h}$. The solution in each well was removed and DMSO $(200 \mu \mathrm{L})$ was then added to each well. The absorbance was recorded on a microplate reader at a wavelength of $575 \mathrm{~nm}$. The $\mathrm{CC}_{50}$ value was calculated by linear regression as the concentration of the compound inhibiting $50 \%$ cellular viability.

\section{Conclusions}

The results found in this study regarding the antimicrobial activity indicate that there are few possibilities of modification on the leubethanol molecule. The dimer of leubethanol, compound 12b showed a higher selectivity index than the natural compound.

\section{Acknowledgments}

Collaborative research performed under the auspices of Mexican Network (PROMEP). R.E. thanks the research contract financed by ISCIII-RICET. B.A. thanks the Ph.D. fellowship received from CONACYT, Mexico.

\section{Author Contributions}

The work presented in this article was made possible thanks to the collaboration between two research groups. R.E., J.P.-M., B.A.-G. and R.S.-A. performed research and analyzed the data; E.O., E.G.-G., 
R.S.-A. and N.W.T. designed research; E.O., R.E. and J.P.-M. wrote the paper. All authors read and approved the final manuscript.

\section{Conflicts of Interest}

The authors declare no conflict of interest.

\section{References and Notes}

1. World Health Organization. WHO Global Tuberculosis Report 2014; WHO: Geneva, Switzerland, 2014.

2. Banerjee, R.; Allen, J.; Westenhouse, J.; Oh, P.; Elms, W.; Desmond, E.; Nitta, A.; Royce, S.; Flood, J. Extensively drug-resistant tuberculosis in California, 1993-2006. Clin. Infect. Dis. 2008, 47, 450-457.

3. Suárez, P.G.; Floyd, K.; Portocarrero, J. Feasibility and costeffectiveness of standardized second-line drug treatment for chronic tuberculosis patients: A national cohort study in Peru. Lancet 2002, 329, 1980-1989.

4. Copp, B.R. Antimycobacterial natural products. Nat. Prod. Rep. 2003, 20, 535-557.

5. Copp, B.R.; Pearce, A.N. Natural product growth inhibitors of Mycobacterium tuberculosis. Nat. Prod. Rep. 2007, 24, 278-297.

6. Newman, D.J.; Craggand, G.M.; Snader, K.M. The influence of natural products upon drug discovery. Nat. Prod. Rep. 2000, 17, 215-234.

7. Butler, M.S.; Buss, A.D. Natural products-The future scaffolds for novel antibiotics? Biochem. Pharmacol. 2006, 71, 919-929.

8. Salomon, C.E.; Schmidt, L.E. Natural products as leads for tuberculosis drug development. Curr. Top. Med. Chem. 2012, 12, 735-765.

9. Rodriguez, A.D.; Ramirez, C. Serrulatane diterpenes with antimycobacterial activity isolated from the West Indian sea whip Pseudopterogorgia elisabethae. J. Nat. Prod. 2001, 64, 100-102.

10. Molina-Salinas, G.M.; Rivas-Galindo, V.M.; Said-Fernández, S.; Lankin, D.C.; Muñoz, M.A.; Joseph-Nathan, P.; Pauli, G.F.; Waksman, N. Stereochemical analysis of leubethanol, an anti-TB-active serrulatane, from Leucophyllum frutescens. J. Nat. Prod. 2011, 74, 1842-1850.

11. Anakok, O.F.; Ndi, C.P.; Barton, M.D.; Griesser, H.J.; Semple, S.J. Antibacterial spectrum and cytotoxic activities of serrulatane compounds from the Australian medicinal plant Eremophila neglecta. J. Appl. Microbiol. 2012, 112, 197-204.

12. Perez-Meseguer, J.; del Olmo, E.; Alanis-Garza, B.; Escarcena, R.; Garza-González, E.; Salazar-Aranda, R.; San Feliciano, A.; Waksman de Torres, N. Synthesis of leubethanol derivatives and evaluation against Mycobacterium tuberculosis. Bioorg. Med. Chem. 2010, 20, 4155-4163. 
13. 2,3,4,6-Tetra- $O$-acetyl- $\beta$-D-glucopyranose was obtained from commercial 2,3,4,6-tetra- $O$-acetyl- $\alpha$ L-glucopyranosyl bromide. To a solution of 2,3,4,6-tetra- $O$-acetyl- $\alpha$-L-glucopyranosyl bromide $(1.62 \mathrm{~g}, 3.94 \mathrm{mmol})$ in absolute acetone $(3 \mathrm{~mL})$ and $\mathrm{H}_{2} \mathrm{O}(0.06 \mathrm{~mL})$ at $0{ }^{\circ} \mathrm{C}$, silver carbonate $(1.85 \mathrm{~g}, 6.70 \mathrm{mmol})$ in small portions was added over $15 \mathrm{~min}$. After stirring for $30 \mathrm{~min}$, the solution was warmed to $60^{\circ} \mathrm{C}$ and filtered. The filter cake was washed with absolute acetone $(3 \times 10 \mathrm{~mL})$, and the combined filtrates evaporated under reduced pressure until most of the solution was filled with crystals. After heating the suspension to dissolve the crystals, an equal volume of absolute diethyl ether and a similar volume of light petroleum were added, and the product crystallized to give $1.10 \mathrm{~g}(80 \%)$ of $2,3,4,6$-tetra- $O$-acetyl- $\beta$-D-glucopyranose as colorless crystals. Then, a solution of the 2,3,4,6-tetra- $O$-acetyl- $\beta$-D-glucopyranose $(0.96 \mathrm{~g}, 2.77 \mathrm{mmol})$ and trichloroacetonitrile $(0.83 \mathrm{~mL}, 8.3 \mathrm{mmol})$ in dry $\mathrm{CH}_{2} \mathrm{Cl}_{2}(5 \mathrm{~mL})$ was treated with finely powdered $\mathrm{K}_{2} \mathrm{CO}_{3}(0.65 \mathrm{~g}, 4.7 \mathrm{mmol})$. The solution was stirred for $20 \mathrm{~h}$ at room temperature and then diluted with dry $\mathrm{CH}_{2} \mathrm{Cl}_{2}(20 \mathrm{~mL})$. The $\mathrm{K}_{2} \mathrm{CO}_{3}$ was filtered off and the filtrate concentrated in vacuo to a total volume of $5 \mathrm{~mL}$ and filtered over silica with $\mathrm{CH}_{2} \mathrm{Cl}_{2} /$ diethyl ether (1:1). The solvent was removed in vacuo and the remaining syrup dissolved in dry diethyl ether to obtain 2,3,4,6-tetra- $O$-acetyl- $\alpha$-D-glucopyranosyl trichloroacetimidate as colorless crystals in $57 \%$ yield.

14. Thompson, M.J.; Hutchinson, E.J.; Stratford, T.H.; Bowlerb, W.B.; Blackburna, G.M. Sugar conjugates of fulvestrant (ICI 182,780): Efficient general procedures for glycosylation of the fulvestrant core. Tetrahedron Lett. 2004, 45, 1207-1210.

15. Mahling, J.A.; Schmidt, R.R. Aryl $C$-glycosides from $O$-glycosyltrichloroacetimidates and phenol derivatives with trimethylsilyl trifluoromethanesulfonate (TMSOTf) as the catalyst. Synthesis 1993, 325-328.

16. Jung, S.-H.; Cho, S.-H.; Dang, T.H.; Lee, J.-H.; Ju, J.-H.; Kim, M.-K.; Lee, S.-H.; Ryu, J.-C.; Kim, Y. Structural requirement of isoflavonones for the inhibitory activity of interleukin-5. Eur. J. Med. Chem. 2003, 38, 537-545.

17. Watanabe, Y.; Shiozaki, M.; Kamegai, R. Synthesis and biological activity of 4',8-dihydroxyisoflavon-7-yl D-hexopyranosides. Carbohydr. Res. 2001, 335, 283-289.

18. Bao, C.; Lu, R.; Jin, M.; Xue, P.; Tan, C.; Zhao, Y.; Liu, G. Synthesis, self-assembly and characterization of a new glucoside-type hydrogel having a Schiff base on the aglycon. Carbohydr. Res. 2004, 339, 1311-1316.

19. Danishesfsky, S.; Yan, C.-F.; Singh, R.K.; Gammill, R.B.; McCurry, P.M.; Fritsch, N.; Clardy, J. Derivatives of 1-methoxy-3-trimethylsilyloxy-1,3-butadiene for Diels-Alder reactions. J. Am. Chem. Soc. 1979, 101, 7001-7008.

20. Nakhai, A.; Bergman, J. Synthesis of hydrogenated indazole derivatives starting with $\alpha, \beta$-unsaturated ketones and hydrazine derivatives. Tetrahedron 2009, 65, 2298-2306.

21. Eal, P.S.; Childers, W.E.; Piwwick, H.W. Oxidation of $\alpha, \beta$-unsaturaed aldehydes. Tetrahedron 1981, 37, 2091-2096.

22. Mycobaterial characterisation: The H37Rv MTB strain (ATCC cat. No. 27294), resulted sensitive to all first-line anti-TB drugs, S, I, R, E and P. Using the conventional BACTEC 460-radiometric system (Bactec 460). 
23. Molina-Salinas, G.; Pérez-López, A.; Becerril-Montes, P.; Salazar-Aranda, R.; Said-Fernández, S.; Waksman de Torres, N. Evaluation of the flora of Northern Mexico for in vitro antimicrobial and antituberculosis activity. J. Ethnopharmacol. 2007, 109, 435-441.

24. Plumb, J.A. Cell sensitivity assays: The MTT assay. In Cancer Cell Culture: Methods and Protocols; Langdon, S.P., Ed.; Humana Press: Totowa, NJ, USA, 2004; pp. 165-169.

Sample Availability: Samples of the reported compounds are available from the authors.

(C) 2015 by the authors; licensee MDPI, Basel, Switzerland. This article is an open access article distributed under the terms and conditions of the Creative Commons Attribution license (http://creativecommons.org/licenses/by/4.0/). 